\title{
Measurement of Average Burnup in TRISO-Coated Particles from AGR-2 UCO Compacts 2-2-2 and 6-4-2
}

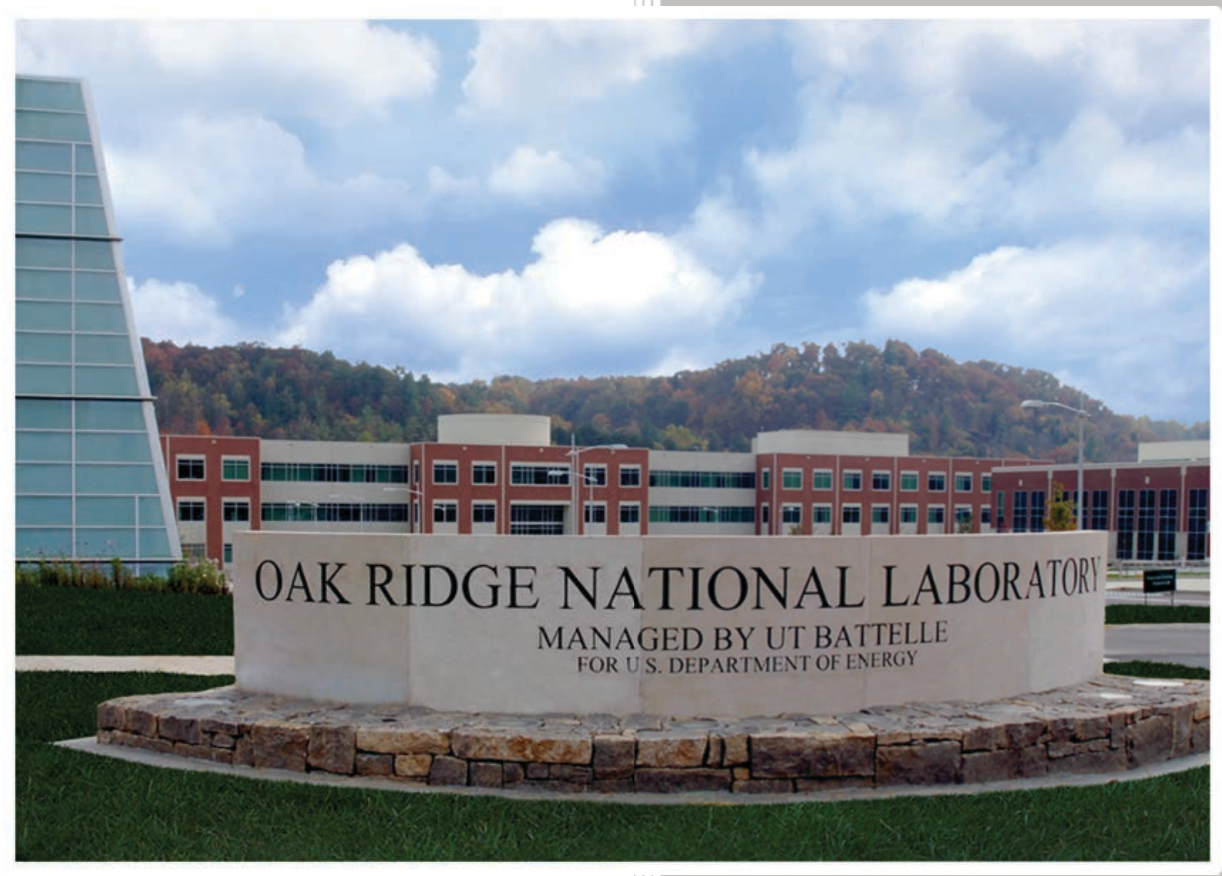

\section{Approved for public release}

Distribution is unlimited

Fred C. Montgomery

John D. Hunn

Tamara J. Keever Benjamin D. Roach

Ralph H. Ilgner Emilie K. Fenske Joseph M. Giaquinto

September 2018 


\section{DOCUMENT AVAILABILITY}

Reports produced after January 1, 1996, are generally available free via US Department of Energy (DOE) SciTech Connect.

Website http://www.osti.gov/scitech/

Reports produced before January 1, 1996, may be purchased by members of the public from the following source:

National Technical Information Service

5285 Port Royal Road

Springfield, VA 22161

Telephone 703-605-6000 (1-800-553-6847)

TDD 703-487-4639

Fax 703-605-6900

E-mail info@ntis.gov

Website http://www.ntis.gov/help/ordermethods.aspx

Reports are available to DOE employees, DOE contractors, Energy Technology Data Exchange representatives, and International Nuclear Information System representatives from the following source:

Office of Scientific and Technical Information

PO Box 62

Oak Ridge, TN 37831

Telephone 865-576-8401

Fax 865-576-5728

E-mail reports@osti.gov

Website http://www.osti.gov/contact.html

This report was prepared as an account of work sponsored by an agency of the United States Government. Neither the United States Government nor any agency thereof, nor any of their employees, makes any warranty, express or implied, or assumes any legal liability or responsibility for the accuracy, completeness, or usefulness of any information, apparatus, product, or process disclosed, or represents that its use would not infringe privately owned rights. Reference herein to any specific commercial product, process, or service by trade name, trademark, manufacturer, or otherwise, does not necessarily constitute or imply its endorsement, recommendation, or favoring by the United States Government or any agency thereof. The views and opinions of authors expressed herein do not necessarily state or reflect those of the United States Government or any agency thereof. 


\title{
MEASUREMENT OF AVERAGE BURNUP IN TRISO-COATED PARTICLES FROM AGR-2 UCO COMPACTS 2-2-2 AND 6-4-2
}

\author{
Fred C. Montgomery \\ John D. Hunn \\ Tamara J. Keever \\ Benjamin D. Roach \\ Ralph H. Ilgner \\ Emilie K. Fenske \\ Joseph M. Giaquinto
}

Date Published: September 2018

\author{
Work sponsored by \\ US DEPARTMENT OF ENERGY \\ Office of Nuclear Energy - Advanced Reactor Technologies \\ under the \\ Advanced Gas Reactor Fuel Development and Qualification Program
}

Prepared by

OAK RIDGE NATIONAL LABORATORY

Oak Ridge, TN 37831-6283

managed by

UT-BATTELLE, LLC

for the

US DEPARTMENT OF ENERGY

under contract DE-AC05-00OR22725 



\section{CONTENTS}

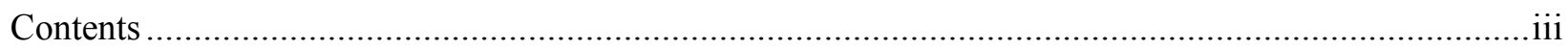

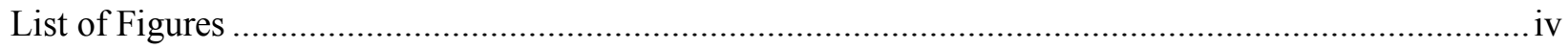

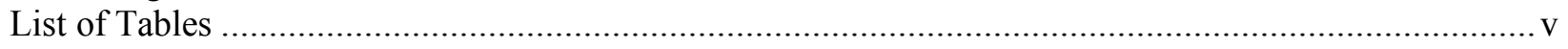

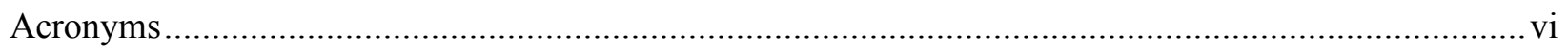

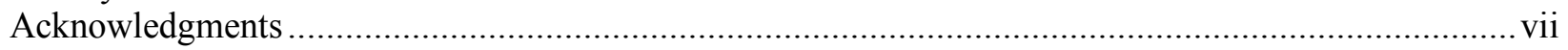

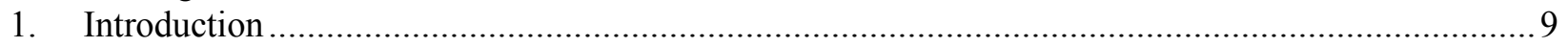

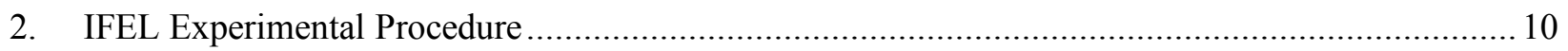

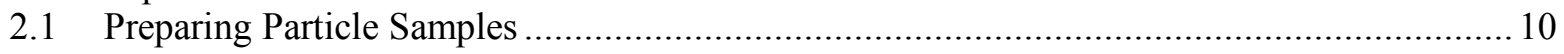

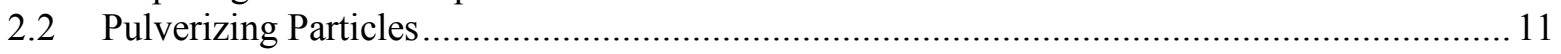

2.3 Burning SPEX ${ }^{\mathrm{TM}}$ Mill bottle and Pulverized Particles ................................................... 12

2.4 leaching with a Soxhlet Extractor ........................................................................ 13

2.5 Weighing extraction samples and Preparing Aliquots for NACIL ..................................... 15

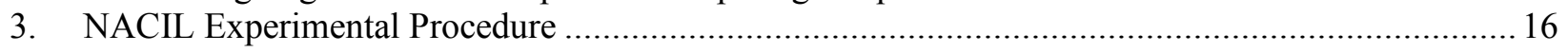

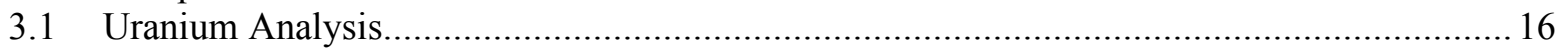

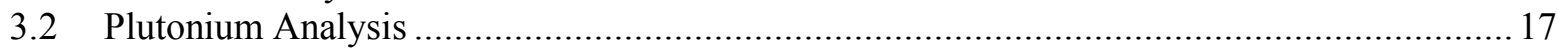

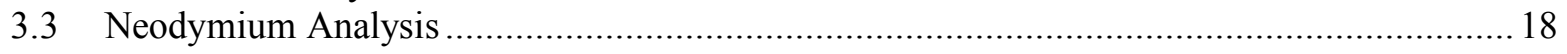

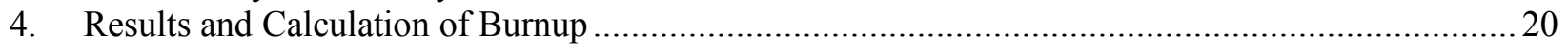

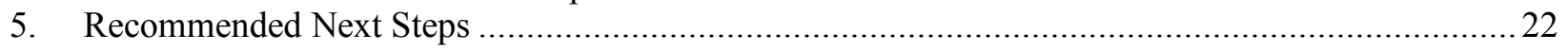

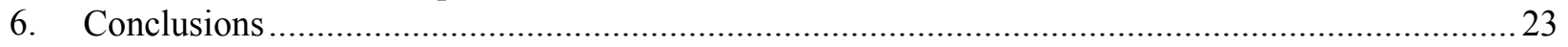

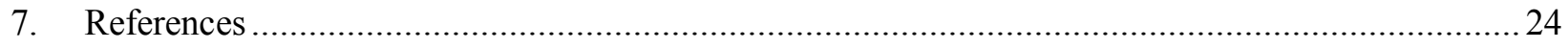

APPENDIX A. Experimentally Measured Elemental Mass and Isotope Fractions ................................26 


\section{LIST OF FIGURES}

1. Images used to count particle samples from Compact 2-2-2 (arbitrary scaling) ................................ 10

2. Images used to count particle samples from Compact 6-4-2 (arbitrary scaling)................................. 11

3. SPEX ${ }^{\mathrm{TM}}$ mill bottle (left), secondary SPEX ${ }^{\mathrm{TM}}$ mill container with O-ring seal (center),

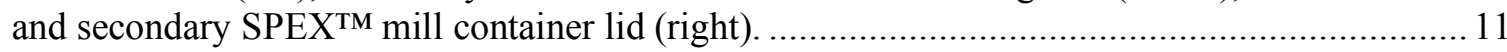

4. Soxhlet thimble with fritted glass disk in bottom (left), quartz reflux flask with manipulator grip and PTFE bushing (center), and ground-glass joint adapter for coupling to Soxhlet

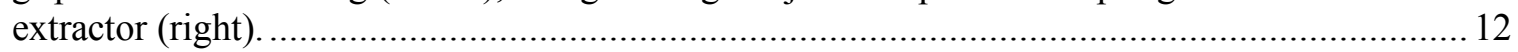

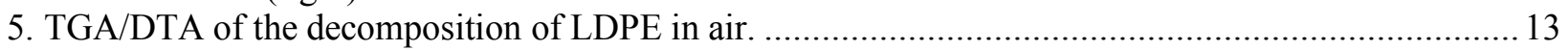

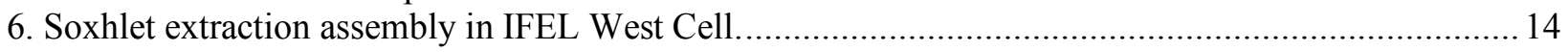

7. Dependency of titrant equivalency on mass of uranium in Davies-Gray analysis solution.................. 17

8. Graphical representation of the relative abundance of eluents as a function of time for the elution profile (Table 5) used in the HPIC elemental isolation of neodymium showing the neodymium elution point.

9. Chromatograms of the unspiked aliquot (above) and ${ }^{150} \mathrm{Nd}$-spiked aliquot (below) from the first extraction of AGR-2 Compact 2-2-2 particle sample 222-A illustrating the separation between the isotopes of neodymium and the isobaric interferences ${ }^{142} \mathrm{Ce},{ }^{144} \mathrm{Ce},{ }^{141} \mathrm{Pr}$, ${ }^{147} \mathrm{Pm},{ }^{147} \mathrm{Sm},{ }^{148} \mathrm{Sm}$, and ${ }^{150} \mathrm{Sm}$. 


\section{LIST OF TABLES}

1. Calculated irradiation conditions for AGR-2 UCO Compacts 2-2-2 and 6-4-2 …............................9

2. Heating ramp used to incinerate LDPE in SPEX ${ }^{\mathrm{TM}}$ mill bottles and oxidize particle debris ................... 13

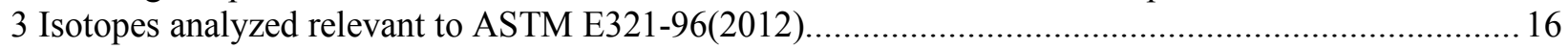

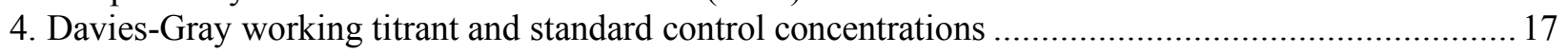

5: Elution profile for the elemental separation of neodymium from all isobaric interferences ................. 18

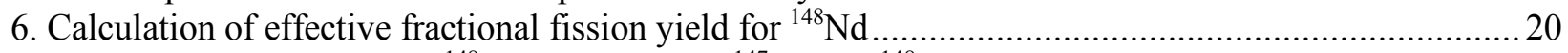

7. Estimated factor to correct ${ }^{148} \mathrm{Nd}$ inventory for ${ }^{147} \mathrm{Nd}(\mathrm{n}, \gamma){ }^{148} \mathrm{Nd}$ neutron capture reaction ...................2 21

8. Burnup in \%FIMA based on fission production of ${ }^{148} \mathrm{Nd}$ for AGR-2 Compacts 2-2-2 and 6-4-2......... 21

9. Results of burnup analysis via the ASTM E321-96(2012) ${ }^{148} \mathrm{Nd}$ method (\%FIMA) ......................... 23 


\section{ACRONYMS}

$\begin{array}{ll}\text { at } \% & \text { Atomic percent } \\ \text { AGR } & \text { Advanced Gas Reactor (Fuel Development and Qualification Program) } \\ \text { AGR-2 } & \text { Second AGR program irradiation experiment } \\ \text { ATR } & \text { Advanced Test Reactor } \\ \text { BWXT-NOG } & \text { BWX Technologies Nuclear Operations Group } \\ \text { CCCTF } & \text { Core Conduction Cooldown Test Facility } \\ \text { CHAR-DAM } & \text { Characterization data acquisition method } \\ \text { CO } & \text { Carbon monoxide } \\ \text { FIMA } & \text { Fission per initial metal atom } \\ \text { HPIC } & \text { High-pressure-ion-chromatography } \\ \text { ICP-MS } & \text { Inductively-coupled plasma mass spectrometry } \\ \text { ID } & \text { Identification } \\ \text { ID-HPIC-ICP-MS } & \text { Isotope-dilution high-pressure-ion-chromatography ICP-MS } \\ \text { ID-ICP-MS } & \text { Isotope-dilution ICP-MS } \\ \text { IFEL } & \text { Irradiated Fuels Examination Laboratory (hot cells) } \\ \text { IMGA } & \text { Irradiated Microsphere Gamma Analyzer } \\ \text { IPyC } & \text { Inner pyrolytic carbon (TRISO layer) } \\ \text { LBL } & \text { Leach-burn-leach } \\ \text { LDPE } & \text { Low-density polyethylene } \\ \text { NACIL } & \text { Nuclear Analytical Chemistry \& Isotopics Laboratory } \\ \text { OPyC } & \text { Outer pyrolytic carbon (TRISO layer) } \\ \text { ORNL } & \text { Oak Ridge National Laboratory } \\ \text { PIE } & \text { Post-irradiation examination } \\ \text { PTFE } & \text { Polytetrafluoroethylene } \\ \text { SiC } & \text { Silicon carbide (TRISO layer) } \\ \text { TA } \text { min }_{\text {TAmax }}^{\text {TAVA }} & \text { Time-averaged minimum temperature } \\ \text { TGA/DTA } & \text { Time-averaged maximum temperature } \\ \text { TRISO } & \text { Time-averaged/volume-averaged temperature } \\ \text { UCO } & \text { Thermogravimetric analysis/differential thermal analyzer (analysis) } \\ \text { wt\% } & \text { Tristructural-isotropic (coated particles) } \\ & \text { Uranium carbide/uranium oxide mixture (fuel kernels) } \\ & \text { weight-percent } \\ & \end{array}$




\section{ACKNOWLEDGMENTS}

This work was sponsored by the U.S. Department of Energy, Office of Nuclear Energy, through the Idaho National Laboratory Advanced Reactor Technologies Technology Development Office as part of the Advanced Gas Reactor Fuel Development and Qualification Program. Analysis of leach solutions was provided by the Oak Ridge National Laboratory Nuclear Analytical Chemistry \& Isotopics Laboratory. Hot cell activities were supported by the staff of the Oak Ridge National Laboratory Irradiated Fuels Examination Laboratory (IFEL). 
ORNL/TM-2018/931 


\section{INTRODUCTION}

Burnup analysis was performed on tristructural-isotropic (TRISO)-coated particles deconsolidated from compacts irradiated by the Advanced Gas Reactor (AGR) Fuel Development and Qualification Program in the second irradiation experiment (AGR-2) [Collin 2014]. The AGR-2 irradiation experiment included TRISO fuel particles with kernels containing both uranium oxide and uranium carbide, called UCO, where uranium carbide is included with the commonly-used uranium oxide in the kernel to provide a getter for oxygen liberated during fission and limit CO production. This allows the UCO-TRISO particles to be taken to higher burnup without failure from excessive internal CO pressure or CO-corrosion of the $\mathrm{SiC}$ layer. The UCO kernels were fabricated and coated at BWX Technologies Nuclear Operations Group (BWXT-NOG) with a 150-mm-diameter engineering-scale coater. The UCO-TRISO batch used in the AGR-2 irradiation experiment was Batch 93073, which had kernels with an average diameter of $426.7 \mu \mathrm{m}$ and average coating thicknesses moving out from the kernel of $98.9 \mu \mathrm{m}$ (buffer), $40.4 \mu \mathrm{m}$ (IPyC), $35.2 \mu \mathrm{m}$ (SiC), $43.4 \mu \mathrm{m}$ (OPyC) [Barnes and Marshall 2009]. The TRISO particle were shipped to ORNL to be formed into compacts for irradiation testing. The compact lot qualified for the AGR-2 irradiation test was lot LEU09-OP2-Z and had an average of 3176 UCO-TRISO particles in each compact [Hunn, Montgomery, and Pappano 2010]. Compilations of the properties data for the particles and compacts are available in a pre-irradiation characterization summary report for the AGR-2 fuel composites [Hunn, Savage, and Silva 2010].

Compacts 2-2-2 and 6-4-2 were irradiated in the Advanced Test Reactor (ATR). Table 1 shows the calculations for expected burnup in percent fission per initial metal atom (FIMA), the fast neutron fluence (neutron energies $\mathrm{E}>0.18 \mathrm{MeV}$ ), and calculated compact temperatures during irradiation. Safety testing was performed on both of these compacts in the ORNL Core Conduction Cooldown Test Facility (CCCTF), where they were heated to $1600{ }^{\circ} \mathrm{C}$ and held at that temperature for $300 \mathrm{~h}$. Results from these safety tests are reported in [Hunn et al. 2016] and [Hunn et al. 2017]. After safety testing, compacts were subjected to the standard suite of destructive post-irradiation examination (PIE) described in detail in [Hunn et al. 2013]. Compact 2-2-2 was electrolytically deconsolidated and TRISO particles were separated from the matrix debris after preburn leaching for survey with the ORNL Irradiated Microsphere Gamma Analyzer (IMGA). After IMGA, an $\sim 90 \%$ fraction of the TRISO particles was subjected to burnleach analysis (matrix debris was subjected to a separate burn-leach). Compact 6-4-2 was also electrolytically deconsolidated but TRISO particles, together with the matrix debris, were subjected to leach-burn-leach (LBL) and the full IMGA survey was not performed. Results from post-safety test PIE of Compact 6-4-2 are documented in [Hunn et al. 2018].

Table 1. Calculated irradiation conditions for AGR-2 UCO Compacts 2-2-2 and 6-4-2

\begin{tabular}{ccccccc}
\hline Compact ID $^{a}$ & Fabrication ID $^{b}$ & $\begin{array}{c}\text { Expected Burnup }^{c} \\
\text { (FIMA) }\end{array}$ & $\begin{array}{c}\text { Fast Fluence }^{c} \\
(\mathrm{E}>0.18 \mathrm{MeV})\end{array}$ & \multicolumn{3}{c}{ Temperature $^{\mathrm{d}}$} \\
\hline AGR-2 2-2-2 & LEU09-OP2-Z075 & $12.55 \%$ & $3.39 \mathrm{E} 25 \mathrm{n} / \mathrm{m}^{2}$ & $1287{ }^{\circ} \mathrm{C}$ & $1189{ }^{\circ} \mathrm{C}$ & $1354{ }^{\circ} \mathrm{C}$ \\
AGR-2 6-4-2 & LEU09-OP2-Z049 & $9.26 \%$ & $2.21 \mathrm{E} 25 \mathrm{n} / \mathrm{m}^{2}$ & $1018{ }^{\circ} \mathrm{C}$ & $894{ }^{\circ} \mathrm{C}$ & $1106{ }^{\circ} \mathrm{C}$ \\
\hline
\end{tabular}

\footnotetext{
${ }^{a}$ The X-Y-Z compact identification (ID) convention denotes the location in the irradiation test train: CapsuleLevel-Stack [Collin 2014].

${ }^{b}$ Physical properties data for individual compacts recorded in [Hunn, Montgomery, and Pappano 2010, 60-69].

${ }^{c}$ Expected burnup [Sterbentz 2014, table 6] and fast fluence [Sterbentz 2014, table 12] are based on physics calculations.

${ }^{d}$ Time-averaged, volume-averaged (TAVA) temperature, time-averaged minimum (TAmin) temperature, and timeaveraged maximum $\left(\mathrm{TA}_{\max }\right)$ temperature are based on thermal calculations [Hawkes 2014, table 3 ].
} 


\section{IFEL EXPERIMENTAL PROCEDURE}

Random samples of post-LBL particles were counted, pulverized, burned, leached with hot nitric acid, leachates weighed, and aliquots prepared for transfer from the hot cell facilities in the Irradiated Fuels Examination Laboratory (IFEL) to the Nuclear Analytical Chemistry \& Isotopics Labs (NACIL) using characterization data acquisition method AGR-CHAR-DAM-49 [Montgomery and Hunn 2018].

\subsection{PREPARING PARTICLE SAMPLES}

Sample preparation was done in the IMGA hot cell where contaminations levels are relatively low, compared to the main IFEL hot cells. Particle samples for burnup analysis were chute riffled from the particles collected from the LBL vessel after the burn-leach. The Compact 6-4-2 particle samples were riffled from a collection of all the particles in the compact, so random sampling error should be limited to the error introduced by chute riffling. While this error is dependent on the particle properties and their variability, experiments carried out by Khan in 1968 found that chute riffling of a binary mixture of fine and coarse sand introduce a 1\% standard deviation in the measured size [Allen 1981]).

The Compact 2-2-2 particle samples were taken from a subset of the particles deconsolidated from the compact ( $\sim 10 \%$ were set aside as a TRISO-coated archive), but this is not expected to have introduced significant additional sampling error. The $\sim 90 \%$ fraction used for Compact $2-2-2$ burn-leach was chute riffled from the full deconsolidated particle collection with the exception of 23 particles. Twenty of these particles were randomly dropped during gamma survey by the IMGA automated vacuum needle handling system and subsequently not added back into the sample to prevent chance of cross-contamination with particles from other compacts; exclusion of these 20 particles will not impact the sampling error. The other three particles were removed during the IMGA survey because of low ${ }^{144} \mathrm{Ce}$ and ${ }^{137} \mathrm{Cs}$ activity. These three particles had radioisotope inventories consistent with other occasionally-observed particles that evidently started the irradiation with abnormally-low ${ }^{235} \mathrm{U}$ content and are presumed to have contained natural uranium UCO kernels that were somehow mixed in with the low-enriched uranium test fuel, based on analysis of similar particles found during AGR-1 PIE [Hunn et al. 2013, 36]. Removal of the three suspect particles before riffling out the burnup samples is actually beneficial for the burnup analysis, as particles that started the irradiation with abnormally-low ${ }^{235} \mathrm{U}$ content would skew the results.

For each compact, two samples of $\sim 200$ particles each were riffled close to the target number of 200 . The riffled samples were imaged and counted to determine the number of particles and a few particles were randomly removed or added from another small, riffled sample to bring the total close to 200. Images of Samples 222-A, 222-B, 642-A, and 642-B are shown in Figure 1 and Figure 2.

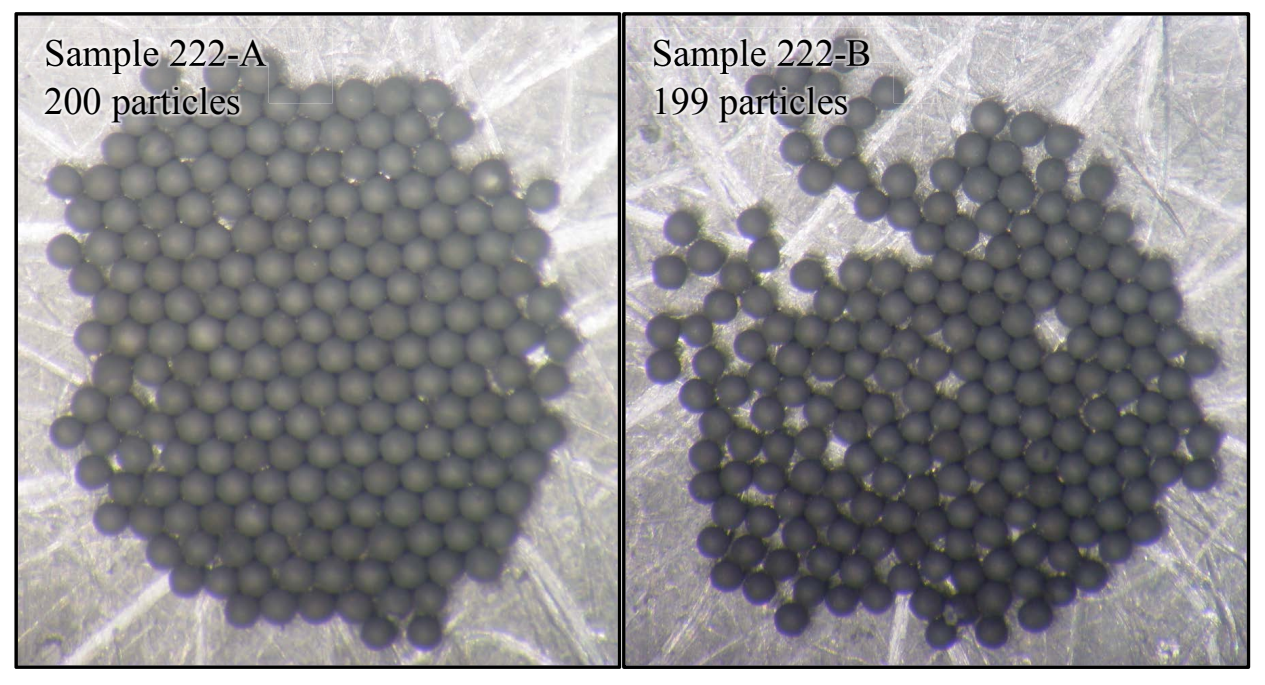

Figure 1. Images used to count particle samples from Compact 2-2-2 (arbitrary scaling). 


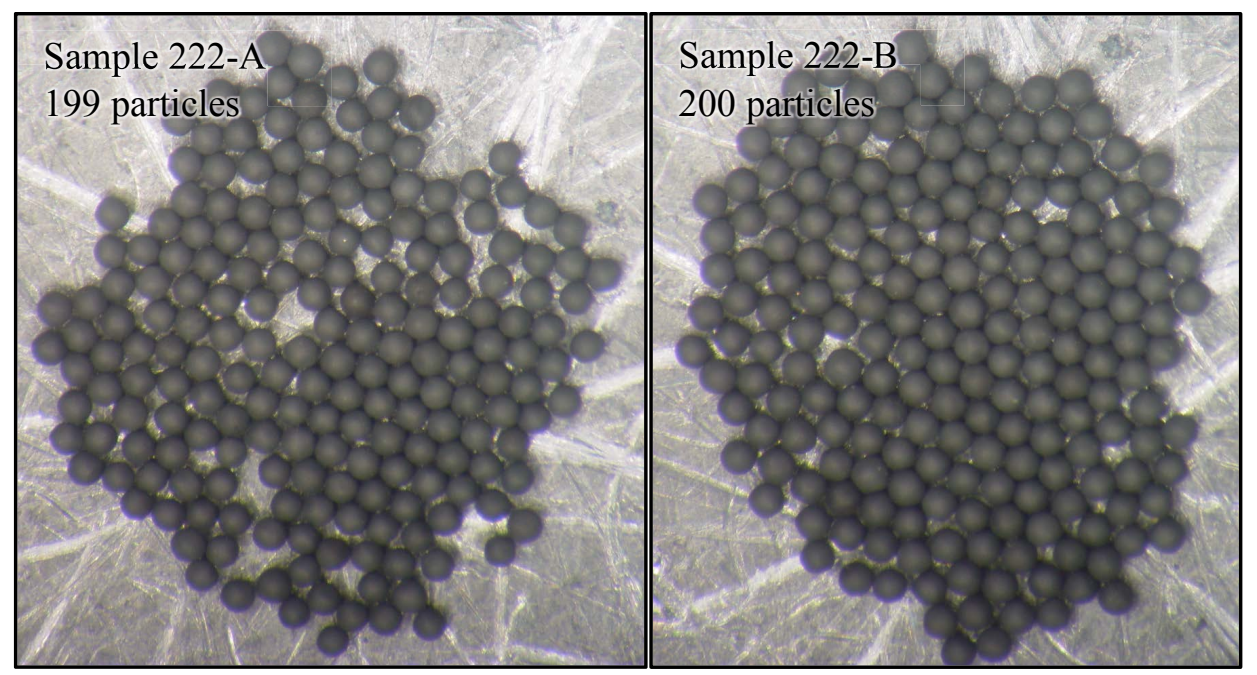

Figure 2. Images used to count particle samples from Compact 6-4-2 (arbitrary scaling).

\subsection{PULVERIZING PARTICLES}

While still in the IMGA cell, the two particle samples from each compact were placed in low-density polyethylene (LDPE) 15-ml narrow-mouth Nalgene ${ }^{\text {tm }}$ bottles from ThermoFisher Scientific selected for containment of the samples during pulverization in the SPEX ${ }^{\text {TM }}$ SamplePrep 8000M mill (Figure 3). The bottles had been previously prepared by labeling, weighing, preloading with about $5 \mathrm{~g}$ ( 55 spheres) of 3-mm yttria-stabilized zirconia grinding media from Tosoh, and reweighing. The bottles containing the samples were bagged to minimize pickup of contamination, then passed through and removed from the IFEL main hot cells. Working in a radiological hood in the IFEL charging area, each SPEX ${ }^{\mathrm{TM}}$ mill bottle was removed from the bag and weighed on a three-place Ohaus Pioneer analytical balance $( \pm 0.002 \mathrm{~g}$ or $\pm 0.002 \%$, whichever is greater) to obtain the particle weight. The bottle was placed in the secondary SPEX ${ }^{\mathrm{TM}}$ mill container shown in Figure 3 and clamped in the SPEX ${ }^{\mathrm{TM}}$ mill. The sample was shaken for 20 minutes in a figure- 8 motion that included short lateral movements combined with back-and-forth swings. After milling, the bottle was removed from the secondary SPEX ${ }^{\mathrm{TM}}$ mill container after a radiological smear verified that the bottle did not leak and contaminate the outer surface. The bottles were then bagged and transferred back to the main hot cell.

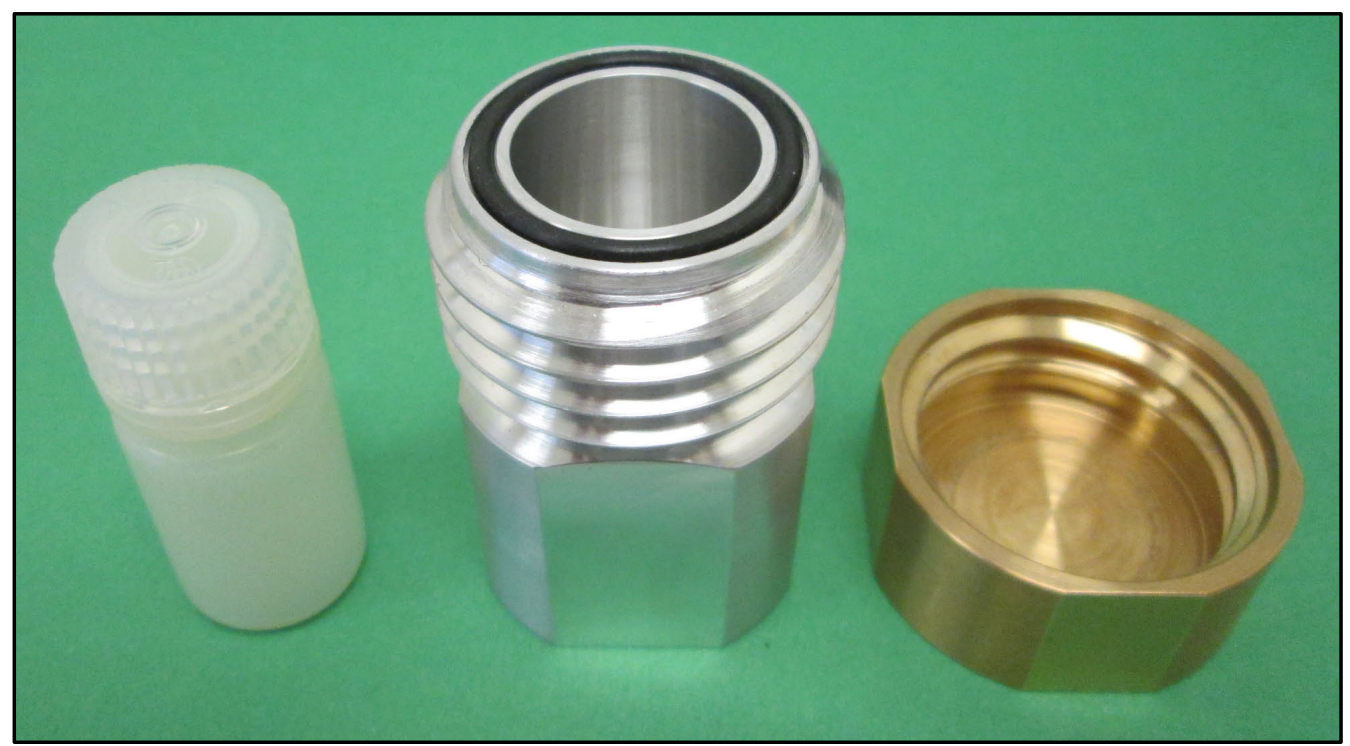

Figure 3. SPEXTM mill bottle (left), secondary SPEXTM mill container with O-ring seal (center), and secondary SPEX ${ }^{\mathrm{TM}}$ mill container lid (right). 


\subsection{BURNING SPEXTM MILL BOTTLE AND PULVERIZED PARTICLES}

Each SPEX ${ }^{\mathrm{TM}}$ mill bottle containing a pulverized particle sample was placed in a new quartz Soxhlet thimble, shown on the left in Figure 4, which was fitted with a \#2 fritted disk (40-90- $\mu \mathrm{m}$ porosity). The thimble was placed into a new quartz $250-\mathrm{ml}$ flat-bottom flask which had a $45 / 50$ ground glass neck, as shown in the center of Figure 4. The flask had a quartz manipulator grip attached to the neck to assist in remote operations. The assembly, without the polytetrafluoroethylene (PTFE) fitting shown in the figure, was covered with a raised, loose fitting cap and was placed into a Neytech Vulcan 3-550 box furnace. The cap protected the sample from contamination and allowed circulation of air into the flask. It had indentations in the lid that held it up off the rim of the flask and had sides which extended over and down the neck.

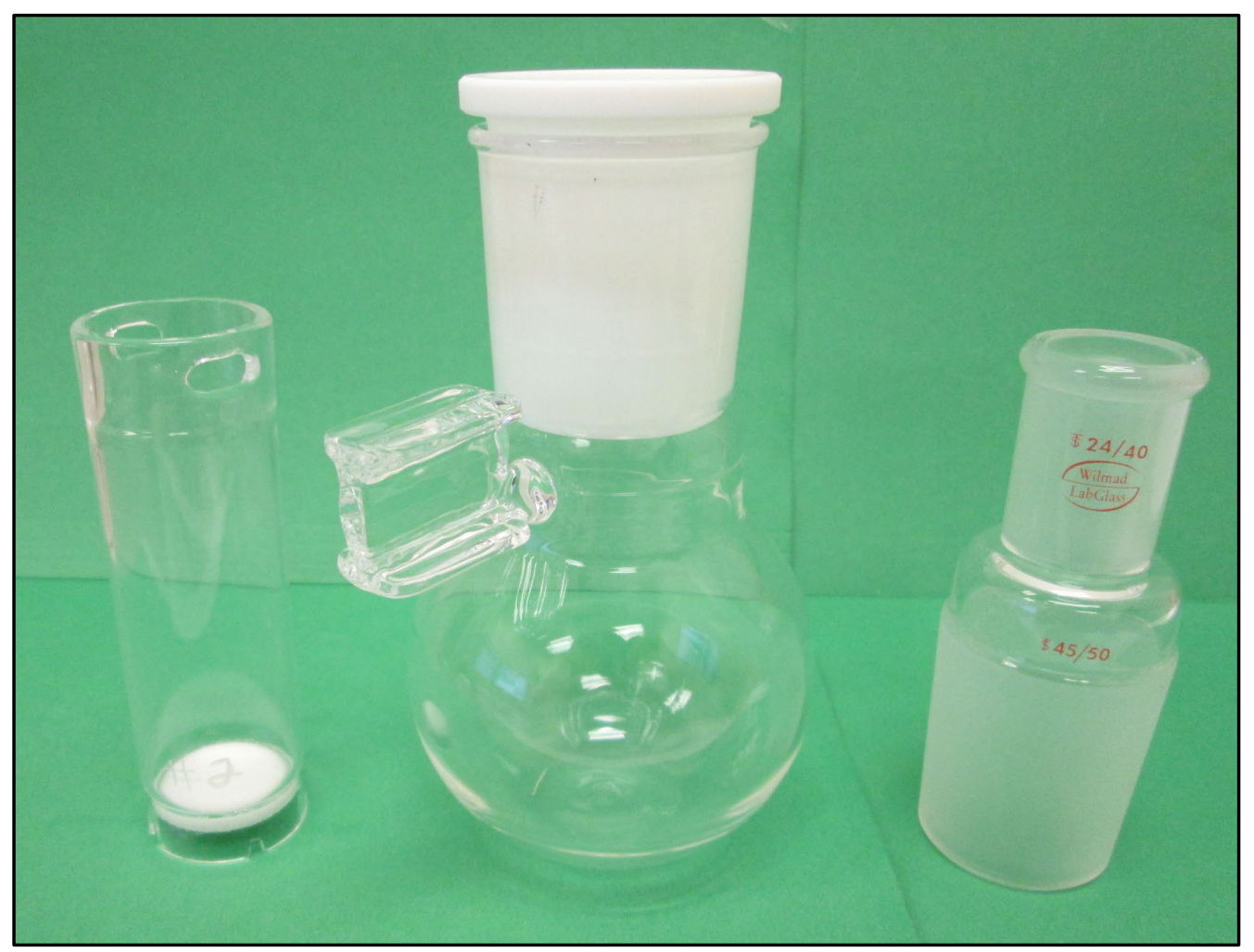

Figure 4. Soxhlet thimble with fritted glass disk in bottom (left), quartz reflux flask with manipulator grip and PTFE bushing (center), and ground-glass joint adapter for coupling to Soxhlet extractor (right).

The LDPE SPEX ${ }^{\mathrm{TM}}$ mill bottle was incinerated by heating at the programmed ramp shown in Table 2. This heating cycle was based on simultaneous thermogravimetric analysis/differential thermal analysis (TGA/DTA) with a TA Instruments Q600 TGA/DTA of the decomposition of LDPE cut from a Nalgene ${ }^{\mathrm{TM}}$ bottle. Figure 5 shows the weight-percent (wt\%) loss and temperature difference between the sample and a reference thermocouple as the sample was heated in air at $10^{\circ} \mathrm{C} / \mathrm{min}$. The LDPE began to lose weight around $250{ }^{\circ} \mathrm{C}$ with the rate of weight loss increasing until $390{ }^{\circ} \mathrm{C}$ where the specimen was losing weight at $16 \mathrm{wt} \% / \mathrm{min}$. Associated with this weight loss was a strong exothermic reaction. The rate of weight loss then slowed until about $400{ }^{\circ} \mathrm{C}$ when a second exothermic reaction occurred, resulting in a maximum rate at $423{ }^{\circ} \mathrm{C}$ of $8.1 \mathrm{wt} \% / \mathrm{min}$. Because of a concern about the possible loss of sample caused by air turbulence during these rapid exothermic reactions, the temperature ramp rate was reduced to $1{ }^{\circ} \mathrm{C} /$ min between $300{ }^{\circ} \mathrm{C}$ and $600{ }^{\circ} \mathrm{C}$ (Table 2). Since most of the bottle would be incinerated by $600{ }^{\circ} \mathrm{C}$, the specified heating rate of $15^{\circ} \mathrm{C} / \mathrm{min}$ to $750{ }^{\circ} \mathrm{C}$ was retained. The furnace was held at $750{ }^{\circ} \mathrm{C}$ for $8 \mathrm{~h}$ to burn off any carbon from the particle coatings and oxidize the kernel material. 
Table 2. Heating ramp used to incinerate LDPE in SPEXTM mill bottles and oxidize particle debris

\begin{tabular}{cccc}
\hline Start Temperature & End Temperature & Ramp Rate & End Temperature Hold Time \\
\hline $25{ }^{\circ} \mathrm{C}$ & $300{ }^{\circ} \mathrm{C}$ & $15^{\circ} \mathrm{C} / \mathrm{min}$ & $15 \mathrm{~min}$ \\
$300^{\circ} \mathrm{C}$ & $600^{\circ} \mathrm{C}$ & $1{ }^{\circ} \mathrm{C} / \mathrm{min}$ & $0 \mathrm{~h}$ \\
$600{ }^{\circ} \mathrm{C}$ & $750^{\circ} \mathrm{C}$ & $15^{\circ} \mathrm{C} / \mathrm{min}$ & $8 \mathrm{~h}$ \\
\hline
\end{tabular}

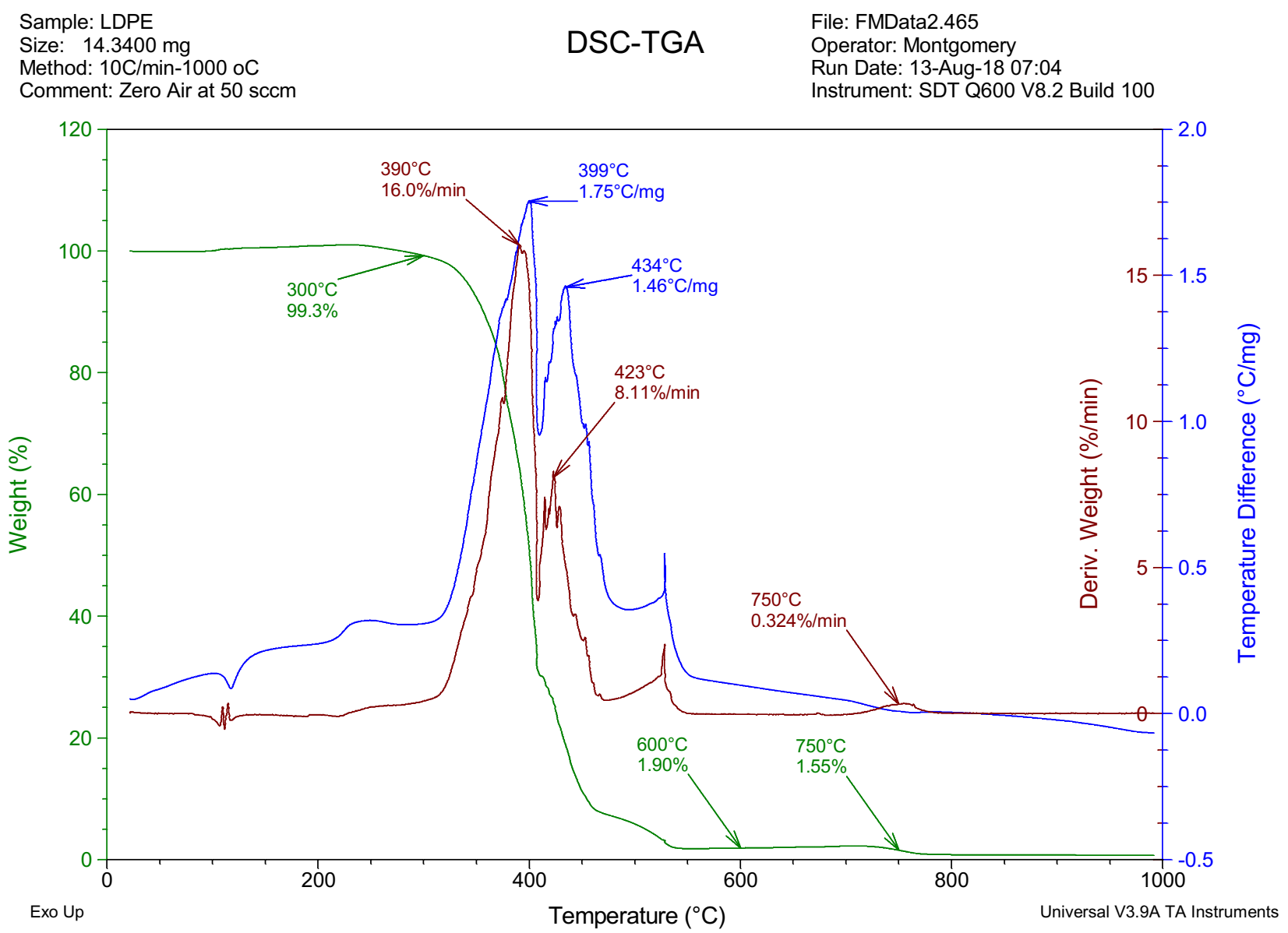

Figure 5. TGA/DTA of the decomposition of LDPE in air.

\subsection{LEACHING WITH A SOXHLET EXTRACTOR}

To avoid contamination from the manipulator grips, a pickup tool that fits into the slots in the top of the thimble was used to transfer the thimble containing the oxidized sample to the body of the $70 \mathrm{ml}$ Soxhlet apparatus shown in Figure 6 . About $100 \mathrm{ml}$ of $67-70 \%$ concentrated MilliporeSigma Omnitrace ${ }^{\circledR}$ nitric acid was added to the $250-\mathrm{ml}$ flat-bottom boiling flask used during the incineration of the bottle. The flask was fitted with a 45/50 to 24/40 PTFE bushing and attached to the Soxhlet apparatus. Heat was applied from a 250-ml flask heating mantle, boiling the acid in the flask. The acid vapors were condensed by a chilled-water Allihn condenser above the Soxhlet body filling it with acid and submerging the sample inside the thimble. When the liquid level reached the top of the siphon tube on the side of the Soxhlet body, the acid drained down into the $250 \mathrm{ml}$ flask and the filling process began again. 
The siphon cycle took about 30 min and washed much of the crushed fine $\mathrm{SiC}$ residue through the \#2 frit down into the $250 \mathrm{ml}$ boiling flask. The coarser \#2 frit was used because, preliminary testing showed that this fine $\mathrm{SiC}$ plugged a \#3 frit (15-40- $\mu \mathrm{m}$ porosity) and reduced the amount of acid that could flush through the frit during the siphon cycle. About $50 \%$ of the extraction acid flushed through the \#2 frit at the end of each cycle. The samples were extracted for $24 \mathrm{~h}$ and then the extraction acid was collected in a previously labeled and tared sample bottle.

To verify the completeness of the extraction a second $24 \mathrm{~h}$ extraction was performed using an additional $100 \mathrm{ml}$ of nitric acid. At the end of this second extraction there were about $30 \mathrm{ml}$ of acid remaining in the Soxhlet. To collect this residual acid, the thimble was removed, and heat was applied to initiate a final flush of the Soxhlet without any holdup by the frit. The second extraction acid was collected in a separate previously labeled and tared sample bottle. The thimble and flask were rinsed with nitric acid and a small amount of high-purity water (ThermoFisher Scientific NERL ${ }^{\text {TM }}$ Type 1). These rinses were added to the second extraction acid sample bottle.

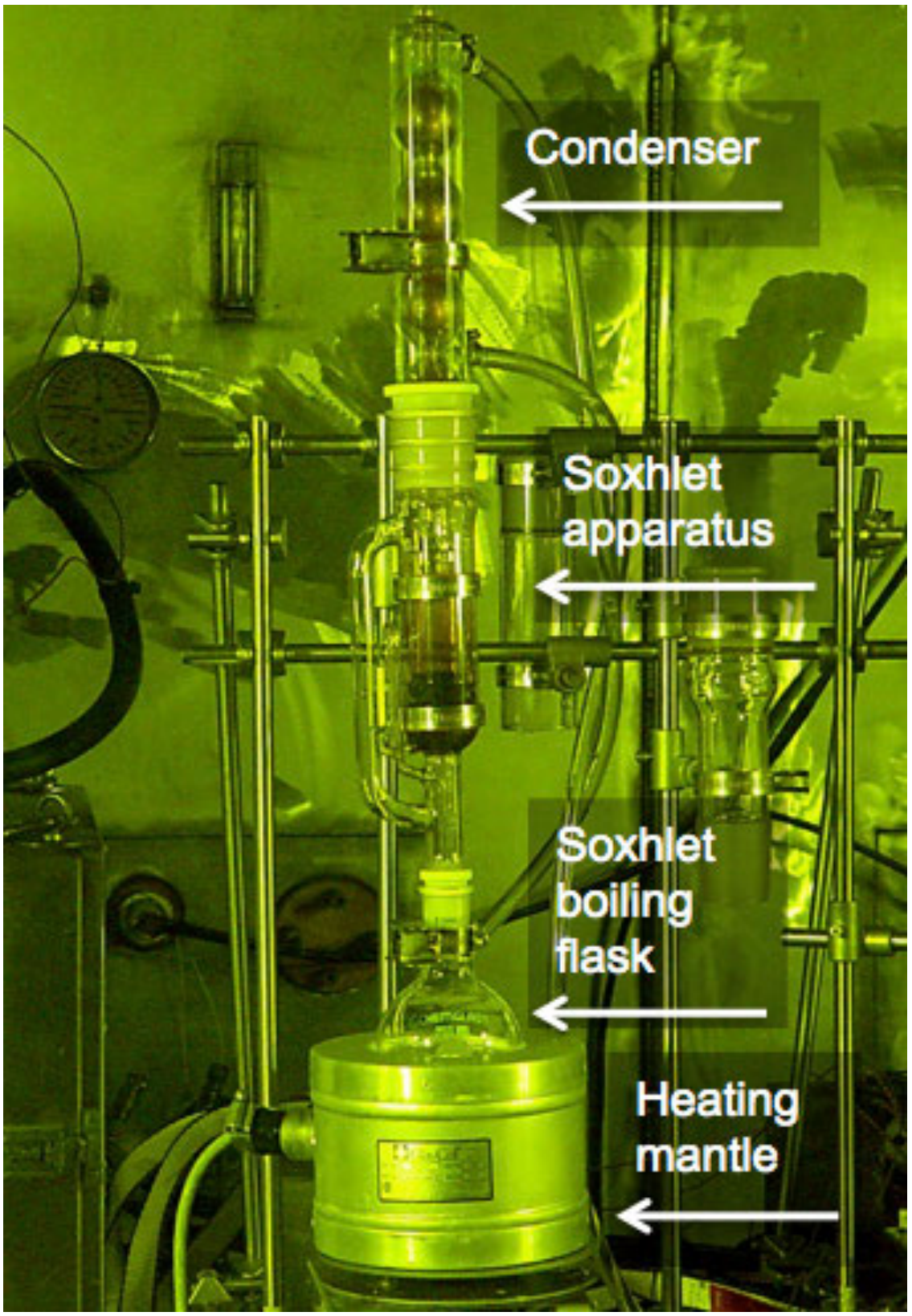

Figure 6. Soxhlet extraction assembly in IFEL West Cell. 


\subsection{WEIGHING EXTRACTION SAMPLES AND PREPARING ALIQUOTS FOR NACIL}

Each extraction acid sample had to be weighed so that analytical chemistry data on the isotopic concentration (measured as a mass fraction) could be converted to the total dissolved mass in each extraction sample. The bottles containing the first and second extraction samples were transferred from the IFEL main hot cell to the radiological hood in the IFEL charging area to be weighed. As with all previous weighing, to assure accurate weights, the balance was verified with check weights before and after the sample weighing. After weighing, the extraction sample bottles were transferred back into the hot cell and aliquots were taken from each sample to provide lower dose subsamples for transfer to NACIL. Each aliquot consisted of 30-50 $\mathrm{ml}$ of the extraction acid and was poured into a previously labeled aliquot bottle that had been stored in the hot cell enclosed in a plastic bag to lessen the possibility of radiological contamination. The bottles with the analysis aliquots were removed from the cell, decontaminated with wet wipes, and sent to the NACIL laboratory for gamma spectroscopy and wet chemical analyses as described in Section 3. 


\section{NACIL EXPERIMENTAL PROCEDURE}

Extraction aliquots were analyzed for plutonium via isotope-dilution inductively-coupled-plasma mass spectrometry (ID-ICP-MS) and for uranium primarily by Davies-Gray titration. Neodymium concentration and isotopic composition were determined via an online direct-injection isotope-dilution high-pressure-ion-chromatography inductively-coupled-plasma mass spectrometry (ID-HPIC-ICP-MS) technique. The concentration measurements of these specific elements and their associated isotopic compositions are necessary for employing the calculations needed to determine fuel burnup using the ASTM E321-96(2012), Standard Test Method for Atom Percent Fission in Uranium and Plutonium Fuel (Neodymium-148 Method). The isotopes of uranium, plutonium, and neodymium that were measured in the aliquots are listed in Table 3.

Table 3 Isotopes analyzed relevant to ASTM E321-96(2012)

\begin{tabular}{cc}
\hline Element & Analyzed isotopes \\
\hline Uranium & $233,234,235,236,238$ \\
Plutonium & $238,239,240,241,242$ \\
Neodymium & $142,143,144,145,146,148,150$ \\
\hline
\end{tabular}

All solutions were analyzed for plutonium and uranium using a quadrupole ICP-MS instruments (ThermoFisher Scientific iCAP-RQ). Fuel aliquots and enriched spike solutions were weighed to four decimal places on the same day. Any dilutions performed were also determined by weighing the solutions. Dilutions were made using ThermoFisher Scientific Optima ${ }^{\mathrm{TM}}$ nitric acid and $>18.2 \mathrm{M} \Omega-\mathrm{cm}$ high-purity type I deionized water from a MilliporeSigma Milli- ${ }^{\circledR}$ water purification system.

Some ICP-MS analyses were performed of other isotopes for possible future comparative burnup calculations $\left({ }^{139} \mathrm{La},{ }^{140} \mathrm{Ce},{ }^{141} \mathrm{Pr},{ }^{142} \mathrm{Ce},{ }^{152} \mathrm{Sm}\right.$, and $\left.{ }^{153} \mathrm{Eu}\right)$. These analyses were made using external standardization via linear regression with commercially available standards from High Purity Standards. The samples were prepared by weighted aliquots and analyzed over separate days and multiple dilutions. An internal standard of ${ }^{115}$ In was employed for matrix correction, though none was noted.

\subsection{URANIUM ANALYSIS}

Uranium isotopic contributions for the aliquots from the first extraction solutions were determined using ICP-MS and the total uranium content was measured using Davies-Gray titration. The uranium content in the second extraction solutions was analyzed by ID-ICP-MS using an enriched spike solution of ${ }^{233} \mathrm{U}$ (New Brunswick Laboratory CRM 111-A) as the isotope dilution internal standard.

Davies-Gray titration was done with slight modifications to ASTM C1201-14, Standard Test Method for Uranium in Presence of Plutonium by Iron(II) Reduction in Phosphoric Acid Followed by Chromium(VI) Titration. The standard procedure was developed using aliquots containing 20-50 $\mathrm{mg}$ of uranium but samples containing about $2.5 \mathrm{mg}$ of uranium have been successfully titrated [ASTM C1204-14]. Because of restrictions on the radiological dose rates in the ORNL NACIL laboratory, the standard Davies-Gray titration procedure was modified slightly to give accurate uranium concentrations on aliquots containing only 5-10 mg of uranium. This involved adjustments to preserve the accuracy and precision of weighing smaller control samples and titrant quantities. Potassium dichromate titrant and uranium standard controls were gravimetrically diluted by approximately $10 \times$ and $20 \times$ respectively. Table 4 shows approximate working solution concentrations prepared to maintain accuracy and precision when performing titrations at Low-Low, and Low uranium levels. 
Table 4. Davies-Gray working titrant and standard control concentrations

\begin{tabular}{ccc}
\hline Davies-Gray Solution & Uranium Control Standard & Titrant \\
\hline Low-Low Level (5 mg U) & $0.5259 \mathrm{mg} / \mathrm{g}$ solution & $0.2125 \mathrm{mg} / \mathrm{g}$ solution \\
Low Level $(20 \mathrm{mg} \mathrm{U})$ & $10.0976 \mathrm{mg} / \mathrm{g}$ solution & $1.5171 \mathrm{mg} / \mathrm{g}$ solution \\
\hline
\end{tabular}

The titrant equivalency $\left(f_{\mathrm{n}}\right)$ is defined by Equation 1 .

$$
f_{n}=(\mathrm{mg} \mathrm{U} \text { in solution}) /(g \text { titrant used to reach equivalence point) (Equation } 1)
$$

Figure 7 shows an example $f_{\mathrm{n}}$ curve for the Low-Low Level titrant concentration in Table 4 and illustrates the sensitivity of $f_{\mathrm{n}}$ on the mass of uranium in the analyzed aliquot. The effect of uranium mass on $f_{\mathrm{n}}$ for analyzed aliquots was taken into consideration by analyzing the sample aliquots and the uranium control standards at similar uranium levels so that the titrant equivalency determined from the control standard would be relevant to the sample aliquot.

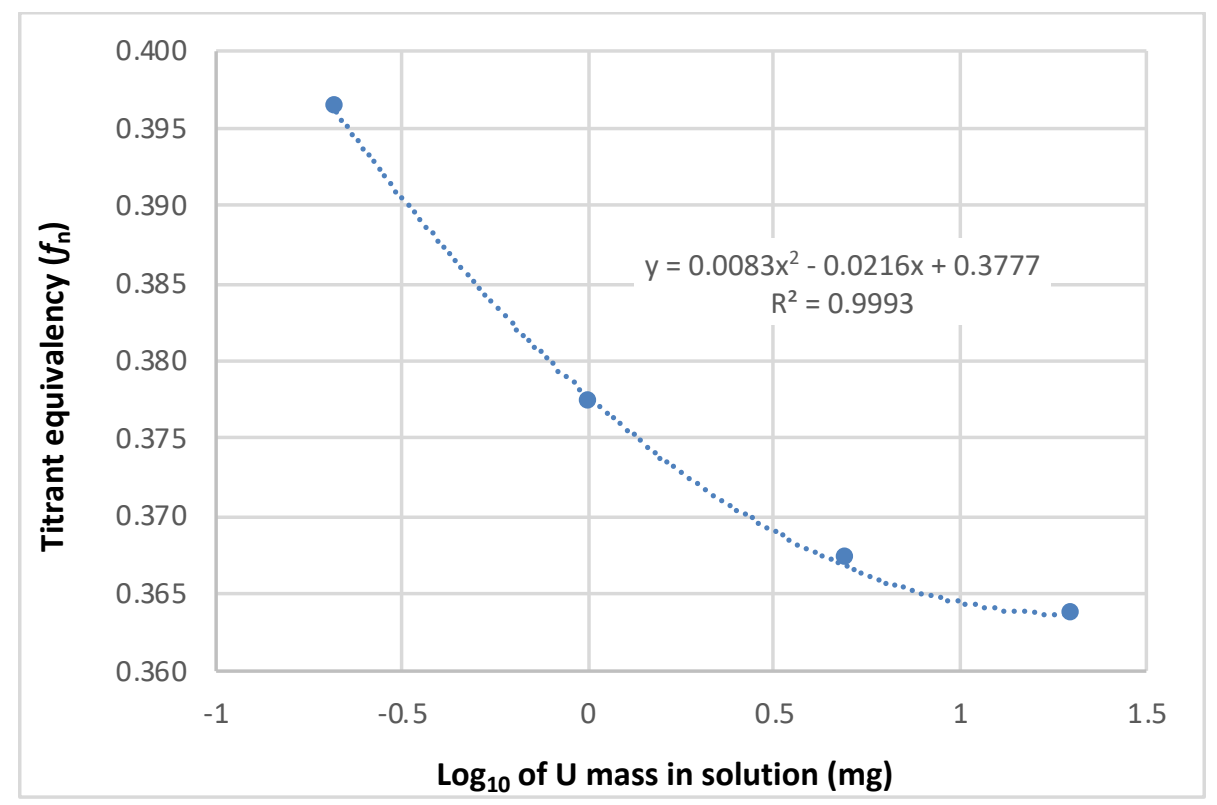

Figure 7. Dependency of titrant equivalency on mass of uranium in Davies-Gray analysis solution.

\subsection{PLUTONIUM ANALYSIS}

Plutonium was determined in the first extraction solutions using ID-ICP-MS after chemical separation with a Bio-Rad AG®MP-1 Anion Exchange Resin 50-100 mesh (chloride form), which had been converted to the nitrate form. A second aliquot from the first extraction solutions was spiked with enriched ${ }^{242} \mathrm{Pu}$ (New Brunswick Laboratory CRM 130) as the isotope dilution internal standard. The second extraction solutions were analyzed for plutonium using linear regression calibration ICP-MS and CRM 130 as the calibration standard. The $\mathrm{wt}^{\mathrm{t}} \%{ }^{240} \mathrm{Pu}$ was determined for the first extraction solution with the isotopic composition obtained from the resin-separated plutonium aliquot used for ID-ICPMS and applied to the calibrated ${ }^{240} \mathrm{Pu}$ response of the second extraction solution to determine total plutonium. The ${ }^{238} \mathrm{Pu}$ was measured via alpha pulse height in the chemically-separated aliquot, along with a ${ }^{239} \mathrm{Pu} /{ }^{240} \mathrm{Pu}$ total via alpha spectrometry, and compared to the mass ratio determined in the ICP-MS fraction. The mass ratio was converted to total ${ }^{239} \mathrm{Pu}+{ }^{240} \mathrm{Pu}$ activity and used in determination of ${ }^{238} \mathrm{Pu}$ content according to ASTM C1415-18, Standard Test Method for ${ }^{238} \mathrm{Pu}$ Isotopic Abundance by Alpha Spectrometry. 


\subsection{NEODYMIUM ANALYSIS}

An online-separation/direct-analysis scheme was used to determine both the concentration and isotopic composition of the neodymium in the first extraction solutions, which were the primary leach of the fuel. The method elementally isolates the neodymium from all natural, non-natural, and polyatomic isobaric interferences yielding a precise isotopic composition. An enriched ${ }^{150} \mathrm{Nd}$ standard was added (ORNL Isotope Business Office) to determine elemental concentration with high accuracy. The second extraction solutions were analyzed using linear regression ICP-MS and a natural neodymium standard from High Purity Standards. The ${ }^{145} \mathrm{Nd}$ isotope $\mathrm{wt} \%$, determined via HPIC separation of the first extraction solution, was applied to the calibrated response of ${ }^{145} \mathrm{Nd}$ in the second extraction solution to determine total neodymium in that solution.

The equipment employed for the ID-HPIC-ICPMS was a ThermoFisher Scientific Dionex ${ }^{\mathrm{TM}}$ ICS-5000 ${ }^{+}$ HPIC system coupled to a ThermoFisher Scientific iCAPTM Q quadrupole ICP-MS. The HPIC system is comprised of a Dionex ${ }^{\mathrm{TM}}$ AS-AP Autosampler, complete with sample dilution and fraction collection capabilities, a gradient mixing pump capable of combining four different eluents in the same analysis, and a thermal compartment containing the injection loop and separation column able to maintain temperatures of $5-85^{\circ} \mathrm{C}$ for constant elution times and reproducibility (measurements were performed at $35^{\circ} \mathrm{C}$ ).

Eluents for HPIC and all other solutions were prepared with trace-metals-basis grade chemicals and ultrapure water $(18.2 \mathrm{M} \Omega-\mathrm{cm})$ from a MilliporeSigma Milli- ${ }^{\circledR}$ water purification system. Chemicals for eluents included recrystallized $>98 \%$ diglycolic acid $\left(\mathrm{C}_{4} \mathrm{H}_{6} \mathrm{O}_{5}\right)$ (Acros Organics lot A0353334) and 99.999\% oxalic acid $\left(\mathrm{C}_{2} \mathrm{H}_{2} \mathrm{O}_{4}\right)$ (Sigma-Aldrich lot MKCC3466). These were dissolved in ultra-pure water, then buffered with ammonium hydroxide $\left(20-22 \%\right.$ as $\left.\mathrm{NH}_{3}\right)$ (ThermoFisher Scientific lot 7115080$)$, to a final $\mathrm{pH}$ of 4.6-4.8. The gradient elution profile is described in Table 5 and Figure 8 . The resultant chromatograms of the unspiked and spiked aliquots from the first extraction of AGR-2 Compact 2-2-2 particle sample 222-A are provided in Figure 9 as an example of the elemental separation.

Table 5: Elution profile for the elemental separation of neodymium from all isobaric interferences

\begin{tabular}{ccccc}
\hline $\begin{array}{c}\text { Interval } \\
\text { Type }\end{array}$ & Time $(\mathrm{s})$ & Deionized $\mathrm{H}_{2} \mathrm{O}(\%)$ & $\begin{array}{c}6 \text { mM Diglycolic Acid } \\
(\%)\end{array}$ & $\begin{array}{c}150 \mathrm{mM} \text { Oxalic Acid } \\
(\%)\end{array}$ \\
\hline Start & 0 & 100 & 0 & 0 \\
Ramp & 300 & 40 & 0 & 60 \\
Hold & 540 & 40 & 0 & 60 \\
Ramp & 546 & 20 & 0 & 80 \\
Ramp & 1080 & 51 & 23 & 26 \\
Ramp & 1380 & 0 & 100 & 0 \\
\hline
\end{tabular}




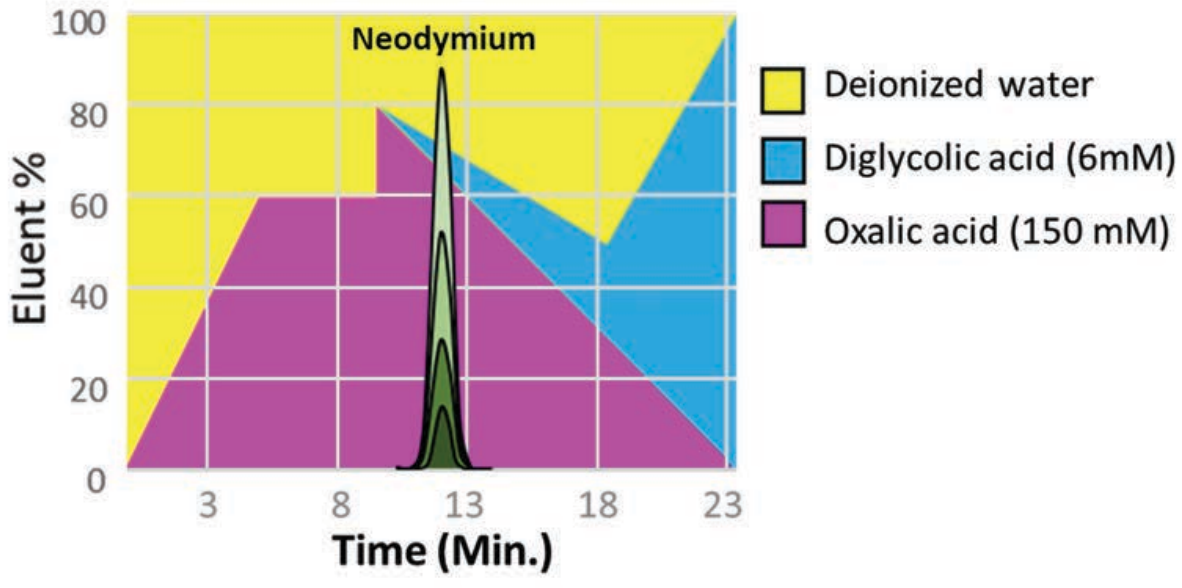

Figure 8. Graphical representation of the relative abundance of eluents as a function of time for the elution profile (Table 5) used in the HPIC elemental isolation of neodymium showing the neodymium elution point.

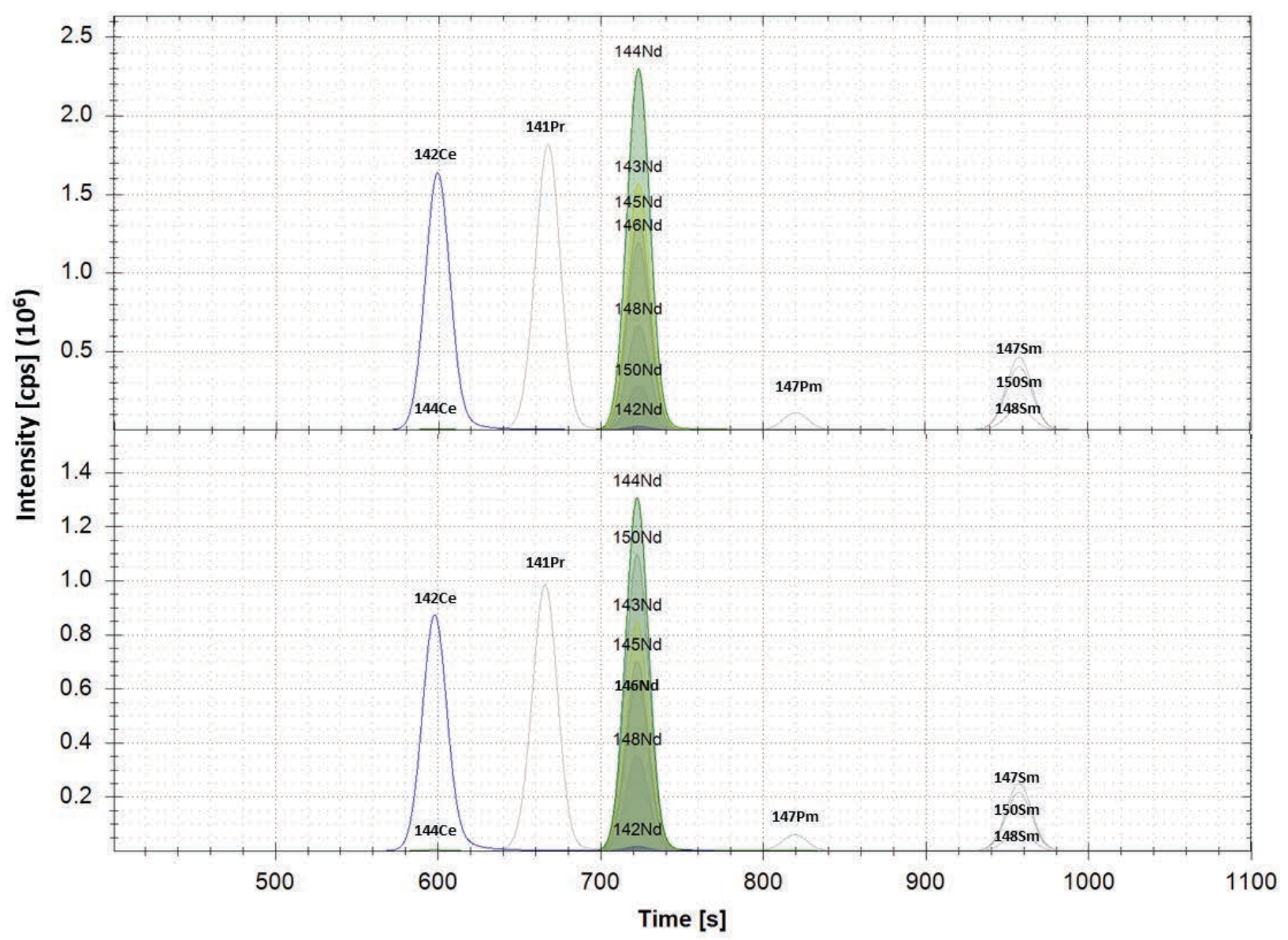

Figure 9. Chromatograms of the unspiked aliquot (above) and ${ }^{150} \mathrm{Nd}$-spiked aliquot (below) from the first extraction of AGR-2 Compact 2-2-2 particle sample 222-A illustrating the separation between the isotopes of neodymium and the isobaric interferences ${ }^{142} \mathrm{Ce},{ }^{144} \mathrm{Ce},{ }^{141} \mathrm{Pr},{ }^{147} \mathrm{Pm},{ }^{147} \mathrm{Sm},{ }^{148} \mathrm{Sm}$, and ${ }^{150} \mathrm{Sm}$. 


\section{RESULTS AND CALCULATION OF BURNUP}

The method in ASTM E321-96(2012) covers measurement of the stable fission product ${ }^{148} \mathrm{Nd}$ to calculate burnup in uranium fuel with an allowable plutonium content up to $50 \%$. The total heavy element atom percent fission $\left(F_{T}\right)$, or \%FIMA, is given by Equation 2, where $F^{\prime}$ is the number of atoms in the fuel that underwent fission and $U^{\prime}$ and $P u^{\prime}$ are the atoms of uranium and plutonium remaining after irradiation. The sum of $U^{\prime}, P u^{\prime}$, and $F^{\prime}$ provides a reasonably accurate determination of the initial heavy metal content of the fuel with negligible error introduced by ignoring the other minor constituents $(\sim 0.14 \%$ error for Compact 2-2-2 and $\sim 0.07 \%$ error for Compact $6-4-2$, based on calculated actinide inventory [Sterbentz 2014]).

$$
F_{T}=\left[F^{\prime} /\left(U^{\prime}+P u^{\prime}+F^{\prime}\right)\right] \times 100
$$

(Equation 2)

The number of fissioned atoms $F^{\prime}$ can be calculated with Equation 3, where $F Y_{E}\left({ }^{148} N d\right)$ is the effective fractional fission yield of ${ }^{148} \mathrm{Nd}$. The ${ }^{148} \mathrm{Nd}$ atoms from fission is determined by correcting the measured atoms of ${ }^{148} \mathrm{Nd}$ for natural contamination and production of ${ }^{148} \mathrm{Nd}$ by the ${ }^{147} \mathrm{Nd}(\mathrm{n}, \gamma)^{148} \mathrm{Nd}$ neutron capture reaction. The natural contamination correction is determined by measuring the content of the shielded isotope ${ }^{142} \mathrm{Nd}$. The effective fractional fission yield of ${ }^{148} \mathrm{Nd}$ is the weighted sum of the fractional fission yield of ${ }^{148} \mathrm{Nd}$ from each heavy metal isotope, with weighting based on each isotope's contribution to the total number of fissions.

$$
F^{\prime}=\left({ }^{148} N d \text { atoms from fission }\right) / F Y_{E}\left({ }^{148} N d\right)
$$

(Equation 3)

The dominant contribution to fission production of ${ }^{148} \mathrm{Nd}$ in the AGR-2 fuel comes from the thermal neutron fissions ${ }^{235} \mathrm{U}_{\mathrm{th}},{ }^{239} \mathrm{Pu}_{\mathrm{th}}$, and ${ }^{241} \mathrm{Pu}$ th and the fast neutron fission ${ }^{238} \mathrm{U}_{\text {fast. }}$ The individual fractional fission yields of ${ }^{148} \mathrm{Nd}$ from these four fission events, the fractional contribution of each to the total number of fissions, and the calculated effective ${ }^{148} \mathrm{Nd}$ fractional fission yields for AGR-2 Compacts 2-2-2 and 6-4-2 are given in Table 6. Ignoring the other fissioning isotopes introduces a negligible error of less than $0.05 \%$. The fractional contribution of each fission event to the total number of fissions was based on the AGR-2 daily depletion simulation [Sterbentz 2014] but any error in the values used is minimized by the fact that the thermal neutron fissions ${ }^{235} \mathrm{U}_{\text {th }}$ and ${ }^{239} \mathrm{Pu}_{\text {th }}$ have similar cumulative fission yields for ${ }^{148} \mathrm{Nd}$.

\begin{tabular}{|c|c|c|c|c|c|}
\hline \multirow{2}{*}{$\begin{array}{c}\text { Fission } \\
\text { event }\end{array}$} & \multirow{2}{*}{$F Y\left({ }^{148} N d\right)^{a}$} & \multicolumn{2}{|c|}{ AGR-2 Compact 2-2-2 } & \multicolumn{2}{|c|}{ AGR-2 Compact 6-4-2 } \\
\hline & & $\%$ Total $^{\mathrm{b}}$ & $F Y_{E}\left({ }^{148} N d\right)$ contribution & $\%$ Total $^{\mathrm{b}}$ & $F Y_{E}\left({ }^{148} N d\right)$ contribution \\
\hline${ }^{235} \mathrm{U}_{\text {th }}$ & $1.6735 \mathrm{E}-02 \pm 5.9 \mathrm{E}-05$ & $79.68 \%$ & $1.333 \mathrm{E}-02 \pm 4.7 \mathrm{E}-05$ & $85.92 \%$ & $1.438 \mathrm{E}-02 \pm 5.0 \mathrm{E}-05$ \\
\hline${ }^{238} \mathrm{U}_{\text {fast }}$ & $2.1125 \mathrm{E}-02 \pm 1.5 \mathrm{E}-04$ & $0.40 \%$ & $8.545 \mathrm{E}-05 \pm 6.0 \mathrm{E}-07$ & $0.36 \%$ & $7.674 \mathrm{E}-05 \pm 5.4 \mathrm{E}-07$ \\
\hline${ }^{239} \mathrm{Pu}_{\mathrm{th}}$ & $1.6421 \mathrm{E}-02 \pm 8.2 \mathrm{E}-05$ & $17.22 \%$ & $2.827 \mathrm{E}-03 \pm 1.4 \mathrm{E}-05$ & $12.69 \%$ & $2.084 \mathrm{E}-03 \pm 1.0 \mathrm{E}-05$ \\
\hline${ }^{241} \mathrm{Pu}_{\mathrm{th}}$ & $1.9321 \mathrm{E}-02 \pm 1.4 \mathrm{E}-04$ & $2.66 \%$ & $5.134 \mathrm{E}-04 \pm 3.6 \mathrm{E}-06$ & $1.00 \%$ & $1.924 \mathrm{E}-04 \pm 1.3 \mathrm{E}-06$ \\
\hline Other & $<2 \mathrm{E}-02$ & $0.04 \%$ & $<8 \mathrm{E}-06$ & $0.03 \%$ & $<6 \mathrm{E}-06$ \\
\hline & & \multicolumn{2}{|c|}{ Compact 2-2-2 FY $Y_{E}\left({ }^{148} N d\right)$} & \multicolumn{2}{|c|}{ Compact 6-4-2 $F Y_{E}\left({ }^{148} N d\right)$} \\
\hline & & \multicolumn{2}{|r|}{$1.676 \mathrm{E}-02 \pm 5 \mathrm{E}-05$} & \multicolumn{2}{|c|}{$1.673 \mathrm{E}-02 \pm 5 \mathrm{E}-05$} \\
\hline
\end{tabular}

Table 6. Calculation of effective fractional fission yield for ${ }^{148} \mathrm{Nd}$

${ }^{a}$ Cumulative fission yields from ENDF/B-VII.1 [Chadwick et al. 2011] were downloaded from www.nndc.bnl.gov.

${ }^{\mathrm{b}}$ The percent each isotope contributed to the total fission was based on AGR-2 physics calculations [Sterbentz 2014].

A table of factors to correct for the ${ }^{147} \mathrm{Nd}(\mathrm{n}, \gamma)^{148} \mathrm{Nd}$ neutron capture reaction based on the neutron flux and fluence is provided in ASTM E321-96(2012). However, the table does not cover the irradiation conditions that were obtained in the AGR-2 irradiation. Suyama and Mochizuki have calculated the effect of the 
${ }^{147} \mathrm{Nd}(\mathrm{n}, \gamma){ }^{148} \mathrm{Nd}$ neutron capture reaction on ${ }^{148} \mathrm{Nd}$ production as a function of the neutron flux and fluence over a range relevant to the AGR-2 samples [Suyama and Mochizuki 2005]. Table 7 shows the estimated total neutron fluence and flux for each sample, where the total neutron fluence was estimated to be five times the fast fluence given in Table 1 and the flux was estimated to be constant over the AGR-2 irradiation period. The percentage of ${ }^{148} \mathrm{Nd}$ produced by the ${ }^{147} \mathrm{Nd}(\mathrm{n}, \gamma){ }^{148} \mathrm{Nd}$ neutron capture reaction during irradiation was taken from Figure 3 of [Suyama and Mochizuki 2005] using these estimated total neutron fluence and flux values and was used to adjust the contamination-corrected amount of ${ }^{148} \mathrm{Nd}$ measured in each sample to account for the ${ }^{148} \mathrm{Nd}$ from neutron capture. The cross sections for ${ }^{146} \mathrm{Nd}(\mathrm{n}, \gamma){ }^{147} \mathrm{Nd}$ and ${ }^{148} \mathrm{Nd}(\mathrm{n}, \gamma)^{149} \mathrm{Nd}$ are more than two orders of magnitude lower than that for ${ }^{147} \mathrm{Nd}(\mathrm{n}, \gamma){ }^{148} \mathrm{Nd}$ [Chadwick et al. 2011], so corrections for these reactions were not necessary.

Table 7. Estimated factor to correct ${ }^{148} \mathrm{Nd}$ inventory for ${ }^{147} \mathrm{Nd}(\mathrm{n}, \gamma)^{148} \mathrm{Nd}$ neutron capture reaction

\begin{tabular}{ccc}
\hline & AGR-2 Compact 2-2-2 & AGR-2 Compact 6-4-2 \\
\hline Fluence $\left(\mathrm{n} / \mathrm{m}^{2}\right)^{\mathrm{a}}$ & $1.7 \mathrm{E} 26$ & $1.1 \mathrm{E} 26$ \\
Flux $\left(\mathrm{n} / \mathrm{m}^{2} \mathrm{~s}\right)^{\mathrm{b}}$ & $3.5 \mathrm{E} 18$ & $2.3 \mathrm{E} 18$ \\
${ }^{148} \mathrm{Nd}$ from ${ }^{147} \mathrm{Nd}(\mathrm{n}, \gamma)^{148} \mathrm{Nd}$ & $2.9 \%$ & $1.9 \%$ \\
\hline
\end{tabular}

${ }^{a}$ Total neutron fluence estimated as $5 \times$ fast fluence from Table 1 .

${ }^{\mathrm{b}}$ Total neutron flux estimated by multiplying estimated total neutron fluence by 559.2 effective full power days [Collin 2014].

${ }^{\mathrm{c}}$ Correction factor taken from Figure 3 of [Suyama and Mochizuki 2005].

Appendix A shows the measurement results for the total inventory extracted from each riffled particle sample of the uranium, plutonium, and neodymium isotopes used in the burnup calculation following the ${ }^{148} \mathrm{Nd}$ method in ASTM E321-96(2012). The calculated burnups are shown in the last row of Table 8. Also included in the table are values that show the impact of not performing the necessary corrections for the conflicting sources of ${ }^{148} \mathrm{Nd}$. The first row shows the burnup values based on using the as-measured ${ }^{148} \mathrm{Nd}$ with no correction for natural contamination or production of ${ }^{148} \mathrm{Nd}$ by the ${ }^{147} \mathrm{Nd}(\mathrm{n}, \gamma){ }^{148} \mathrm{Nd}$ neutron capture reaction when calculating $F^{\prime}$ in Equation 3. The second row only includes the correction for natural contamination. A small amount of natural ${ }^{142} \mathrm{Nd}$ was detected in the extraction samples. The ${ }^{142} \mathrm{Nd}$ isotope is not formed significantly through fission because it is shielded by stable ${ }^{142} \mathrm{Ce}$. This makes it a convenient marker for natural contamination. Naturally-occurring neodymium is $27.152 \%{ }^{142} \mathrm{Nd}$ and $5.756 \%{ }^{148} \mathrm{Nd}$ [Berglund and Wieser 2011]. Based on the concentration of ${ }^{142} \mathrm{Nd}$ measured in each sample, the amount of ${ }^{148} \mathrm{Nd}$ from natural contamination was calculated by Equation 4 and subtracted from the measured amount of ${ }^{148} \mathrm{Nd}$.

$$
{ }^{148} N d_{\text {contamination }}=\left({ }^{142} \mathrm{Nd} / 0.27152\right) \times 0.05756
$$

Table 8. Burnup in \%FIMA based on fission production of ${ }^{148} \mathrm{Nd}$ for AGR-2 Compacts 2-2-2 and 6-4-2

\begin{tabular}{ccccc}
\hline \multirow{2}{*}{ Corrections Applied } & \multicolumn{4}{c}{ Particle sample } \\
& $222-\mathrm{A}$ & $222-\mathrm{B}$ & $642 \mathrm{~A}$ & $642 \mathrm{~B}$ \\
\hline no corrections & $13.12 \pm 0.22$ & $13.19 \pm 0.26$ & $10.28 \pm 0.20$ & $9.81 \pm 0.19$ \\
just natural Nd contamination & $12.97 \pm 0.22$ & $13.04 \pm 0.26$ & $10.20 \pm 0.20$ & $9.74 \pm 0.19$ \\
all corrections & $\mathbf{1 2 . 6 4} \pm \mathbf{0 . 2 5}$ & $\mathbf{1 2 . 7 1} \pm \mathbf{0 . 2 9}$ & $\mathbf{1 0 . 0 3} \pm \mathbf{0 . 2 2}$ & $\mathbf{9 . 5 7} \pm \mathbf{0 . 2 1}$ \\
\hline
\end{tabular}




\section{RECOMMENDED NEXT STEPS}

Other stable fission product isotopes can also be used to compute the number of fissions that occur during irradiation. Several methods for calculation of nuclear fuel burnup in TRISO particles were explored during AGR-1 PIE [Harp et al. 2014]. These included non-destructive gamma spectroscopy methods and destructive chemical analysis followed by mass spectroscopy. Six isotopes were identified by Harp et al. as reliable fission indicators for the AGR fuel: ${ }^{139} \mathrm{La},{ }^{140} \mathrm{Ce},{ }^{142} \mathrm{Ce},{ }^{141} \mathrm{Pr}$, and the sum of ${ }^{145} \mathrm{Nd}$ and ${ }^{146} \mathrm{Nd}$. Additional calculations should be performed to calculate burnup using these and other isotopes that were measured during the AGR-2 Compact 2-2-2 and 6-4-2 sample analyses.

As mentioned in Section 3, several isotopes $\left({ }^{139} \mathrm{La},{ }^{140} \mathrm{Ce},{ }^{141} \mathrm{Pr},{ }^{142} \mathrm{Ce},{ }^{152} \mathrm{Sm}\right.$, and $\left.{ }^{153} \mathrm{Eu}\right)$ were measured using a typical external standardization ICP-MS technique in addition to the high-accuracy measurements of the neodymium isotopes by isotope dilution and ion-exchange chromatography. The data available for isotopes other than ${ }^{148} \mathrm{Nd}$ offer additional opportunities for comparative calculation of the burnup in these samples. As was done for ${ }^{148} \mathrm{Nd}$, these calculations should include, where possible and necessary, corrections for natural contamination and production/destruction of the fission indicating isotope due to neutron capture. Neutron capture correction factors for each isotope could be based on estimations from known cross sections for the relevant reactions, as was done for ${ }^{148} \mathrm{Nd}$ in ASTM E321-96(2012).

However, a more direct estimation of the correction factor might be obtained by extracting information on the fraction of each isotope that was formed and lost during the AGR-2 irradiation test from the daily depletion simulation [Sterbentz 2014]. The availability of the necessary simulation data has been confirmed and the extraction of the relevant information will only require modification of the data postprocessors.

Comparisons of the burnup estimates obtained from the available isotope data can be compared with consideration of the preferred properties of a burnup indicator as discussed in ASTM E321-96(2012) and [Harp et al. 2014].

1) Low volatility or diffusive release of the isotope and its precursors is preferred. Previously obtained safety testing and LBL data is available for AGR-2 Compacts 2-2-2 and 6-4-2 that provide information on fractional loss of most of the isotopes of interest and will help interpret some of the differences that may be observed between the various burnup calculations. Diffusive release of ${ }^{153} \mathrm{Eu}$ is a particular issue for Compact 2-2-2, which was irradiated at a temperature that increased diffusive release during the irradiation test to above $10 \%$.

2) All isotopes currently of interest are stable isotopes and this simplifies the analysis in that decay correction is not required.

3) Low cross sections for neutron capture that result in production or destruction of the fission indicator is preferable. Where cross sections are higher, availability of an accurate correction factor is important. A comparative study will highlight the impact of high cross sections for some isotopes, such as ${ }^{151} \mathrm{Sm}(\mathrm{n}, \gamma){ }^{152} \mathrm{Sm}$ and ${ }^{152} \mathrm{Eu}(\mathrm{n}, \gamma){ }^{153} \mathrm{Eu}$, which have cross sections around $10 \mathrm{~kb}$.

4) ASTM E321-96(2012) identifies that ${ }^{148} \mathrm{Nd}$ has good characteristics for mass spectrometry. This can be considered for the other isotopes of interest.

5) Fission yields from ${ }^{235} \mathrm{U}$ and ${ }^{239} \mathrm{Pu}$ should be similar and high yields can reduce measurement uncertainty.

6) Low contamination or a convenient shielded isotope, such as ${ }^{142} \mathrm{Nd}$, for contamination correction is important for maximum accuracy.

7) It is important that the isotope of interest have a high solubility in the leachate. Concentrated nitric acid was used for the extractions performed on the particle samples from Compact 2-2-2 and 6-4-2. Addition of other acids, such as $\mathrm{HF}$ and $\mathrm{HCl}$, or variation in the sample preparation methods prior to leaching can increase the solubility of some elements. Harp et al. studied the addition of HF and variation of the burn temperature. 


\section{CONCLUSIONS}

A procedure was developed and approved to pulverize and leach isotopes for burnup calculations from TRISO particle fuel samples using the ORNL IFEL hot cell facilities [Montgomery and Hunn 2018]. This procedure was applied to two $\sim 200$-particle samples taken from the burn-leach archives of $1600^{\circ} \mathrm{C}$ safetytested AGR-2 Compacts 2-2-2 and 6-4-2. The samples were analyzed for uranium, plutonium, and neodymium using Davies-Gray titration and ICP-MS methods designed to produce high-accuracy data through the use of isotope dilution for internal standardization. Additional accuracy was obtained in the neodymium analysis using a ThermoFisher Scientific Dionex ${ }^{\mathrm{TM}}$ ICS-5000 direct-injection HPIC system coupled to the ICP-MS to isolate the neodymium isotopes from isobaric interferences from other isotopes via ion chromatography. Burnup was calculated from the data using the in ASTM E321-96(2012) ${ }^{148} \mathrm{Nd}$ method.

According to ASTM E321-96(2012), ${ }^{148} \mathrm{Nd}$ is considered an ideal candidate for burnup analysis because of its low volatility, good characteristics for mass spectrometry, similar fission yield from ${ }^{235} \mathrm{U}$ and ${ }^{239} \mathrm{Pu}$, and availability of the ${ }^{142} \mathrm{Nd}$ shielded isotope for natural-neodymium contamination correction. The preferred property of low volatility was further bolstered by previously-performed LBL and safety testing, which showed inconsequential loss of neodymium (as well as uranium and plutonium) from the fuel particles prior to its extraction for the burnup analysis (releases were $<0.1 \%$ for Compact $2-2-2$ and $<0.01 \%$ for Compact 6-4-2).

Also critical for the accurate determination of burnup via ${ }^{148} \mathrm{Nd}$ analysis is accurately accounting for the ${ }^{147} \mathrm{Nd}(\mathrm{n}, \gamma){ }^{148} \mathrm{Nd}$ neutron capture reaction. If not accurately determined, this correction could introduce a systematic error of several percent. A correction was estimated based on a paper by Suyama and Mochizuki and the average neutron flux and fluence for Compacts 2-2-2 and 6-4-2. A more rigorous correction can be determined from the daily depletion simulation [Sterbentz 2014] and that effort is in progress. Obtaining the correction for neutron capture in this manner will also account for the fact that the 11-day half-life ${ }^{147} \mathrm{Nd}$ decayed significantly during the reactor shutdowns that occurred throughout the AGR-2 irradiation test and the impact of reactor shutdowns were not accounted for in the continuousirradiation calculation by Suyama and Mochizuki.

Table 9 shows the calculated burnup in \%FIMA for the analyzed samples and compares the average to the burnup estimated with the JMOCUP Monte Carlo depletion methodology [Sterbentz 2014]. The calculated burnup via the ${ }^{148} \mathrm{Nd}$ method was higher than the values obtained by the daily as-run physics depletion model [Sterbentz 2014]. Agreement between Sample 222-A and Sample 222-B was very good and well within the estimated uncertainty. However, this was not the case for the two Compact 6-4-2 samples, which deviated by almost $5 \%$. The dominant source of this deviation may have been in the measurement of the remaining uranium, which was the largest value in Equation 2 and differed between Sample 642-A and 642-B by 8\% (Appendix A). Analysis of three samples from each compact was originally planned but was reduced to two to reduce the time and cost required for the analysis, based on the preliminary results from the first two Compact 2-2-2 samples exhibiting a deviation below the measurement uncertainty. The analysis of Compact 6-4-2 would benefit from inclusion of analysis of the third 200-particle sample taken from that compact, as this might elucidate whether one of the other results was impacted by an abnormal error.

Table 9. Results of burnup analysis via the ASTM E321-96(2012) ${ }^{148} \mathrm{Nd}$ method (\%FIMA)

\begin{tabular}{crrrc}
\hline Compact & Sample A & Sample B & \multicolumn{1}{c}{ Average } & [Sterbentz 2014] \\
\hline AGR-2 2-2-2 & $12.64 \pm 0.25$ & $12.71 \pm 0.29$ & $12.68 \pm 0.19$ & 12.55 \\
AGR-2 6-4-2 & $10.03 \pm 0.22$ & $9.57 \pm 0.21$ & $9.80 \pm 0.15$ & 9.26 \\
\hline
\end{tabular}




\section{REFERENCES}

ASTM C1204-14. 2014. Standard Test Method for Uranium in Presence of Plutonium by Iron(II) Reduction in Phosphoric Acid Followed by Chromium(VI) Titration. West Conshohocken, PA: ASTM International.

ASTM C1415-18. 2018. Standard Test Method for ${ }^{238}$ Pu Isotopic Abundance by Alpha Spectrometry. West Conshohocken, PA: ASTM International.

ASTM E321-96(2012). 2012. Standard Test Method for Atom Percent Fission in Uranium and Plutonium Fuel (Neodymium-148 Method). West Conshohocken, PA: ASTM International.

Allen, T. 1981. Particle Size Measurement. New York, NY: Chapman and Hall.

Barnes, C.M., and D.W. Marshall. 2009. FY 2009 Particle Fabrication and Coater Test Report. INL/EXT-09-16545, Revision 0. Idaho Falls, ID: Idaho National Laboratory.

Berglund, M., and M.E. Wieser. 2011. "Isotopic Compositions of the Elements." Pure Appl. Chem. 83(2): 397-410.

Chadwick, M.B., et al. 2011. "ENDF/B-VII.1 Nuclear Data for Science and Technology: Cross Sections, Covariances, Fission Product Yields and Decay Data." Nuclear Data Sheets 112, 2887-2996. Data downloaded from www.nndc.bnl.gov.

Collin, B.P. 2014. AGR-2 Irradiation Test Final As-Run Report. INL/EXT-14-32277, Revision 2. Idaho Falls, ID: Idaho National Laboratory.

Harp, J.M., P.A. Demkowicz, P.L. Winston, and J.W. Sterbentz. 2014. “An Analysis of Nuclear Fuel Burnup in the AGR-1 TRISO Fuel Experiment Using Gamma Spectrometry, Mass Spectrometry, and Computational Simulation Techniques." Nucl. Eng. Design 278: 395-405.

Hawkes, G.L. 2014. AGR-2 Daily As-Run Thermal Analyses. INL/ECAR-2476, Revision 1. Idaho Falls, ID: Idaho National Laboratory.

Hunn, J.D., F.C. Montgomery, and P.J. Pappano. 2010. Data Compilation for AGR-2 UCO Variant Compact Lot LEU09-OP2-Z. ORNL/TM-2010/017, Revision 1. Oak Ridge, TN: Oak Ridge National Laboratory.

Hunn, J.D., T.W. Savage, and C.M. Silva. 2010. AGR-2 Fuel Compact Pre-Irradiation Characterization Summary Report. ORNL/TM-2010/226, Revision 0. Oak Ridge, TN: Oak Ridge National Laboratory.

Hunn, J.D., R.N. Morris, C.A. Baldwin, F.C. Montgomery, C.M. Silva, and T.J. Gerczak. 2013. AGR-1 Irradiated Compact 4-4-2 PIE Report. ORNL/TM-2013/236, Revision 0. Oak Ridge, TN: Oak Ridge National Laboratory.

Hunn, J.D., R.N. Morris, C.A. Baldwin, and F.C. Montgomery. 2016. Safety Testing of AGR-2 UCO Compacts 5-2-2, 2-2-2, and 5-4-1. ORNL/TM-2016/423, Revision 0. Oak Ridge, TN: Oak Ridge National Laboratory.

Hunn, J.D., R.N. Morris, C.A. Baldwin, Z.M. Burns, F.C. Montgomery, and D.J. Skitt. 2017. Safety Testing of AGR-2 UCO Compacts 6-4-2 and 2-3-1. ORNL/TM-2017/439, Revision 0. Oak Ridge, TN: Oak Ridge National Laboratory.

Hunn, J.D., T.J. Gerczak, F.C. Montgomery, D.J. Skitt, C.A. Baldwin, G.W. Helmreich, B.D. Eckhart, and J.A. Dyer. 2018. AGR-2 As-Irradiated UCO Compact 6-4-2 PIE Report. ORNL/TM-2018/864, Revision 0. Oak Ridge, TN: Oak Ridge National Laboratory.

Montgomery, F.C., and J.D. Hunn. 2018. Data Acquisition Method: Burnup Measurement of Irradiated Fuel Particles. AGR-CHAR-DAM-49, Revision 0. Oak Ridge, TN: Oak Ridge National Laboratory.

Sterbentz, J.W. 2014. JMOCUP As-Run Daily Depletion Calculation for the AGR-2 Experiment in the ATR B-12 Position. ECAR-2066, Revision 2. Idaho Falls, ID: Idaho National Laboratory. 
Suyama, K. and H. Mochizuki. 2005. "Effect of Neutron Induced Reactions of Neodymium-147 and 148 on Burnup Evaluation.” J. Nucl. Science and Technology 42(7): 661-669. 


\section{APPENDIX A. EXPERIMENTALLY MEASURED ELEMENTAL MASS AND ISOTOPE FRACTIONS}

\begin{tabular}{|c|c|c|c|c|}
\hline Isotope & Sample 222-A & Sample 222-B & Sample 642-A & Sample 642-B \\
\hline total U (mg) & $69.275 \pm 0.105$ & $67.679 \pm 0.088$ & $64.083 \pm 0.115$ & $69.570 \pm 0.124$ \\
\hline${ }^{233} \mathrm{U}(\mathrm{at} \%)$ & $0.0000 \pm 0.0000$ & $0.0000 \pm 0.0000$ & $0.0000 \pm 0.0000$ & $0.0000 \pm 0.0000$ \\
\hline${ }^{234} \mathrm{U}(\mathrm{at} \%)$ & $0.1060 \pm 0.0021$ & $0.1067 \pm 0.0021$ & $0.1201 \pm 0.0024$ & $0.1213 \pm 0.0024$ \\
\hline${ }^{235} \mathrm{U}(\mathrm{at} \%)$ & $2.7732 \pm 0.0555$ & $2.7954 \pm 0.0559$ & $5.3096 \pm 0.0531$ & $5.3814 \pm 0.0538$ \\
\hline${ }^{236} \mathrm{U}(\mathrm{at} \%)$ & $2.1400 \pm 0.0428$ & $2.1734 \pm 0.0435$ & $1.6901 \pm 0.0338$ & $1.6977 \pm 0.0339$ \\
\hline${ }^{238} \mathrm{U}(\mathrm{at} \%)$ & $94.9808 \pm 0.9498$ & $94.9245 \pm 0.9492$ & $92.8802 \pm 0.9288$ & $92.7996 \pm 0.9280$ \\
\hline total $\mathrm{Pu}(\mathrm{mg})$ & $1.0188 \pm 0.0201$ & $0.9694 \pm 0.0191$ & $0.8976 \pm 0.0020$ & $1.0229 \pm 0.0029$ \\
\hline${ }^{238} \mathrm{Pu}(\mathrm{at} \%)$ & $1.8382 \pm 0.0367$ & $1.8027 \pm 0.0361$ & $0.8980 \pm 0.045$ & $0.7182 \pm 0.036$ \\
\hline${ }^{239} \mathrm{Pu}(\mathrm{at} \%)$ & $51.0348 \pm 0.5104$ & $50.9938 \pm 0.5099$ & $62.9658 \pm 0.630$ & $63.2226 \pm 0.632$ \\
\hline${ }^{240} \mathrm{Pu}(\mathrm{at} \%)$ & $27.9560 \pm 0.2796$ & $27.9881 \pm 0.2799$ & $25.8848 \pm 0.259$ & $25.9246 \pm 0.259$ \\
\hline${ }^{241} \mathrm{Pu}(\mathrm{at} \%)$ & $11.4198 \pm 0.1142$ & $11.4864 \pm 0.1149$ & $7.7148 \pm 0.077$ & $7.6321 \pm 0.153$ \\
\hline${ }^{242} \mathrm{Pu}(\mathrm{at} \%)$ & $7.7512 \pm 0.0775$ & $7.7291 \pm 0.0773$ & $2.5366 \pm 0.051$ & $2.5026 \pm 0.050$ \\
\hline${ }^{244} \mathrm{Pu}(\mathrm{at} \%)$ & $0.0000 \pm 0.0000$ & $0.0000 \pm 0.0000$ & $0.0000 \pm 0.000$ & $0.0000 \pm 0.000$ \\
\hline total Nd (mg) & $1.2605 \pm 0.0070$ & $1.2298 \pm 0.0144$ & $0.8952 \pm 0.0093$ & $0.9230 \pm 0.0102$ \\
\hline${ }^{142} \mathrm{Nd}(\mathrm{at} \%)$ & $0.5411 \pm 0.0054$ & $0.5429 \pm 0.0054$ & $0.3175 \pm 0.0064$ & $0.3132 \pm 0.0063$ \\
\hline${ }^{143} \mathrm{Nd}(\mathrm{at} \%)$ & $17.7622 \pm 0.1776$ & $17.7307 \pm 0.1773$ & $21.8339 \pm 0.2183$ & $22.1606 \pm 0.2216$ \\
\hline${ }^{144} \mathrm{Nd}(\mathrm{at} \%)$ & $35.8937 \pm 0.3589$ & $35.9966 \pm 0.3600$ & $32.1685 \pm 0.3217$ & $31.9225 \pm 0.3192$ \\
\hline${ }^{145} \mathrm{Nd}(\mathrm{at} \%)$ & $17.0592 \pm 0.1706$ & $16.9449 \pm 0.1694$ & $18.0614 \pm 0.1806$ & $18.0611 \pm 0.1806$ \\
\hline${ }^{146} \mathrm{Nd}(\mathrm{at} \%)$ & $16.6424 \pm 0.1664$ & $16.5791 \pm 0.1658$ & $15.8016 \pm 0.1580$ & $15.7235 \pm 0.1572$ \\
\hline${ }^{148} \mathrm{Nd}(\mathrm{at} \%)$ & $8.5791 \pm 0.0858$ & $8.6391 \pm 0.0864$ & $8.4602 \pm 0.0846$ & $8.4603 \pm 0.0846$ \\
\hline${ }^{150} \mathrm{Nd}(\mathrm{at} \%)$ & $3.5223 \pm 0.0358$ & $3.5668 \pm 0.0357$ & $3.3570 \pm 0.0336$ & $3.3587 \pm 0.0336$ \\
\hline
\end{tabular}

